Felix Suerkemper, Johannes Thema, Stefan Thomas, Florian Dittus, Monthon Kumpaengseth, Milou Beerepoot

\title{
Benefits of Energy Efficiency Policies in Thailand: An Ex-ante Evaluation of the Energy Efficiency Action Plan
}

Originally published in:

Energy Efficiency,

9 (2016) 1, pp. 187-210

DOI:

10.1007/s12053-015-9357-Z 
Felix Suerkemper a

Johannes Thema a

Stefan Thomas a

Florian Dittus $b$

Monthon Kumpaengseth c

Milou Beerepoot c

\section{Benefits of Energy Efficiency}

Policies in Thailand:

An Ex-ante Evaluation of the

Energy Efficiency Action

Plan

a Wuppertal Institut für Klima, Umwelt, Energie gGmbH, Germany

b indepecon Unternehmergesellschaft, Germany

c Deutsche Gesellschaft für Internationale Zusammenarbeit (GIZ) c/o Energy Policy and Planning Office (EPPO), Thailand

* Corresponding author:

Felix Suerkemper

Wuppertal Institut für Klima, Umwelt, Energie gGmbH

Germany

E-mail:

felix.suerkemper@wupperinst.org

Phone: +4930288745817

Fax: +49 331-2881302

This is the author's version of a work that was accepted for publication. Changes resulting from the publishing process, such as editing, corrections and structural formatting, may not be reflected in this document. Changes may have been made to this work since it was submitted for publication. A definitive version was subsequently published in the Journal cited above. 


\begin{abstract}
The paper presents the results of an ex-ante evaluation of the economy-wide benefits that may be achieved through the implementation of the 20-year Energy Efficiency Action Plan (EEAP) in Thailand. The objective of the EEAP is to reduce energy intensity by $25 \%$ in 2030 compared to 2010 . This is to be reached by reducing the projected energy consumption by $20 \%$ or 38 Mtoe until 2030. We have specified an analytical framework, which allows for a calculation of the overall energy cost savings, energy import cost reductions and reduced $\mathrm{CO}_{2}$ emissions. Moreover, we calculated the induced energy efficiency investments, employment effects and impacts on governmental budget. The evaluation shows that an effective implementation of the plan may lead to a reduction in energy expenditure of 37.7 billion EUR by 2030. Moreover, the EEAPinduced energy savings will significantly reduce the greenhouse gas emissions as well as Thailand's energy import costs and generate private investment in energy efficiency of about 5 billion EUR annually in 2030, which in turn may lead to about 300,000 new jobs. The size of the net impact of the plan on Thailand's governmental budget is uncertain due to positive and negative effects on corporate and income tax revenues, expenses for unemployment benefits, governmental energy consumption, expenses for energy subsidies and energy tax income.
\end{abstract}

\title{
Keywords
}

Energy Efficiency Action Plan (EEAP); Thailand; economic benefits of energy efficiency; ex-ante evaluation

\section{Introduction}

Over the last few decades, Thailand has experienced a transformation from an agricultural into a semi-industrialised economy (Phdungsilp 2010). As a result of strong economic growth, ${ }^{1}$ the final energy consumption in Thailand has drastically increased and is expected to rise further in the future (Shrestha et al. 2007). The transport and industrial sectors accounted for $34 \%\left(21,194 \mathrm{ktoe}^{2}\right)$ and $29 \%$ (18,381 ktoe) respectively of total final energy consumption in 2010 (APEC 2012). A significant rise of residential electricity consumption has also taken place amongst others due to a higher appliance endowment in households (refrigeration, air conditioning, electric fans, television etc.), made possible through the increased disposable income. Final energy consumption per capita has more than doubled from 0.39 toe $3 /$ person to 0.96 toe/person between 1990 and 2013 (EPPO 2014). In addition, the Thai population has been growing continuously from around 55.8 million in 1990 to 68.3 million inhabitants in 2013 (annual population growth between $0.6 \%$ and 1.3\%) (EPPO 2014). Energy demand in Thailand is forecasted to increase rapidly: Phdungsilp and Wuttipornpun (2013) expect it to more than double within the next two decades with major environmental and energy security implications. The International Energy Agency (IEA 2013a) forecasts primary energy demand to grow at an average rate of $2.3 \%$ per year between 2011 and 2035, which would equal a doubling in three decades. $\mathrm{CO}_{2}$-emissions grew at an average rate of $7.6 \%$ per year between 1980 and 2010 (Phdungsilp 2013) and are expected to increase in the future from $243 \mathrm{Mt} \mathrm{CO}_{2}$ in 2011 to $460 \mathrm{Mt} \mathrm{CO}_{2}$ in 2035 corresponding to an average growth rate of $2.7 \%$ (IEA 2013a).

\footnotetext{
${ }^{1}$ Average real GDP growth rates were at $4.2 \%$ between 2002 and 2012 (BOT 2013).

${ }^{2}$ kilotonne of oil equivalent. $1 \mathrm{ktoe}=41.9 \mathrm{TJ}=11.6 \mathrm{GWh}($ IEA 2015).

${ }^{3}$ tonne of oil equivalent.
} 
Due to a limited availability of domestic energy resources, Thailand strongly depends on energy imports (AIT 2010).4 The country spent 12\% of its GDP in 2012 on energy imports (EPPO 2013). In 2011, 73\% of the consumed oil came from imported stock (EDMC 2012). According to EPPO (2011), the rate of energy imports per total energy consumption increases every year, for example from $48 \%$ in 2009 to $51 \%$ in 2010 . The IEA (2013a) expects Thailand's net gas and oil import costs to rise from almost 30 billion US-Dollars in 2011 to around 100 billion US-Dollars in 2035. Energy supply security in terms of dependency on energy imports, continuously increasing energy costs, as well as increasing pollution and greenhouse gas (GHG) emissions are therefore future key challenges for Thailand (Thepkhun et al. 2013).

With the enforcement of the Thai Energy Conservation Promotion Act, B.E. 2535 (1992), the improvement of energy efficiency has been established as an important means to address these future energy challenges. In the wake of the Act, the Government implemented, among other policy measures, appliance-related energy efficiency measures, which have resulted in substantial energy demand savings (du Pont 2014; Foran et al. 2010). At the Asia Pacific Economic Cooperation (APEC) Summit in 2007, Thai government leaders ratified the collaboration in energy conservation promotion to meet the agreed target in 2030. In response to this, the Thai Energy Policy and Planning Office (EPPO) under the Ministry of Energy (MOEN) developed a 20-year Energy Efficiency Development Plan/ EEDP (2011 - 2030), which was approved in 2011 to provide a national policy framework and guidelines on energy conservation in the long term (GIZ 2013).

As an update of the EEDP and for its implementation, a more detailed Energy Efficiency Action Plan (EEAP) has been elaborated for Thailand in 2013 (Ministry of Energy 2013). The overall aim of the EEAP is to reduce energy intensity in 2030 by $25 \%$ compared to 2010, which is equivalent to a reduction of final energy consumption by $20 \%$ or about 38,00o kilotonnes of crude oil equivalent (ktoe) relative to baseline projections in 2030 (Figure 1). Priority sectors for the implementation of energy efficiency measures are transportation and industry (Ministry of Energy 2013).

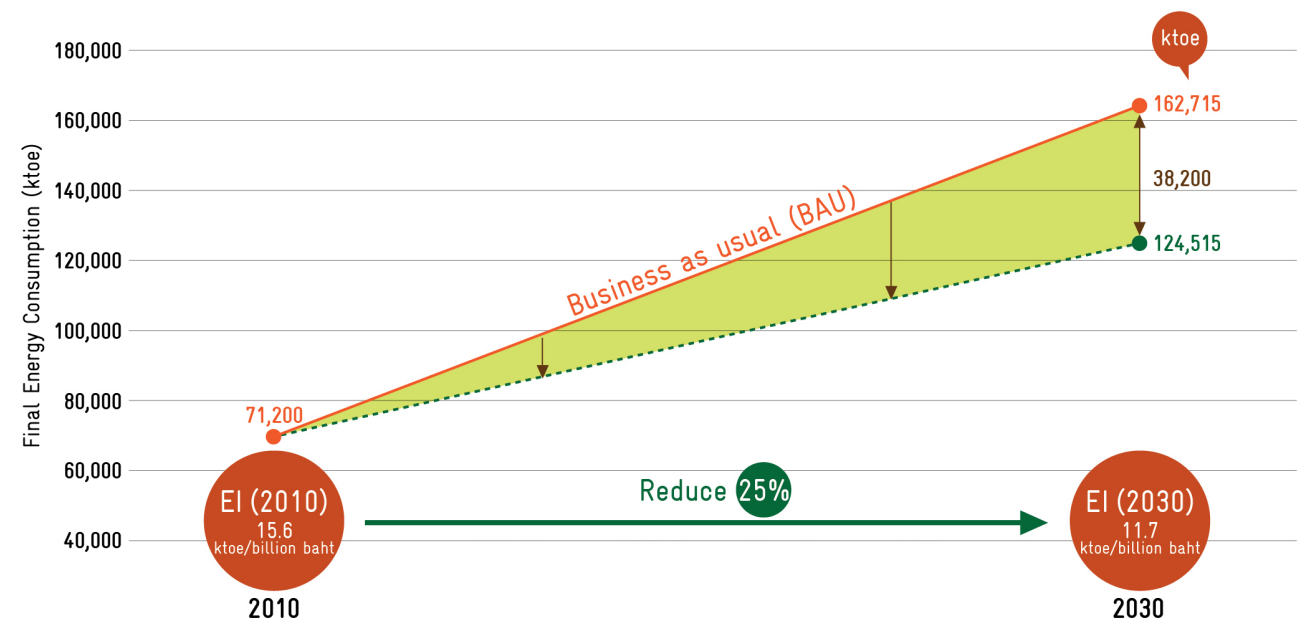

Figure 1 Thai EEAP energy efficiency targets

Source: German International Cooperation (2015) Based on Ministry of Energy (2013)

${ }^{4}$ While energy security was enhanced by expanding domestic hydropower between the 1960 s and 1990 s, such infrastructure projects have been facing tremendous public opposition since the mid-1990s (Greacen \& Palettu 2007). 
In order to achieve the targets, a combination of 34 different energy efficiency measures will be implemented. They consist of mandatory measures such as laws, regulations and standards as well as promotional/supportive measures like R\&D promotion, incentive provision, public awareness/behaviour change campaigns, human resources and capacity building. The 20-year EEAP strategy is divided into three implementation phases: short-term (2011-2016), medium-term (2017-2022) and long-term (2023-2030). For each phase a different set of concrete energy efficiency measures is planned.

Currently, further energy reforms are untertaken, and the EEAP will be incorporated into an integrated National Energy Development Plan through 2035, which is currently under development as part of the overall reform process in Thailand.

The implementation of the EEAP measures is expected to deliver numerous benefits for the Thai economy. The objective of this paper is to provide an analytical framework for evaluating the economy-wide benefits that may result from the energy savings realised as expected in the EEAP. The derived analytical framework will then be applied in order to ex-ante evaluate, how energy efficiency policies may help to address the key Thai energy challenges. Such an ex-ante EEAP assessment is not publicly available, 5 but is considered important to inform the government, industry, public and other stakeholders in Thailand about the expected impacts and their magnitude of a successfully implemented EEAP. This study does not assess whether the energy savings will actually be realised as expected in the EEAP. We use the projected savings data as provided by the EEAP as the main input variable and assume energy savings to be net of potential rebound effects. ${ }^{6}$

This study is based on research conducted as part of a GIZ/EPPO programme in which these two partners support Thai institutions with the implementation of the energy efficiency plans. Our methodological approach allows for a first ex-ante calculation of the energy cost savings, energy import cost savings and reduced $\mathrm{CO}_{2}$ emissions. Moreover, induced energy efficiency investments, employment effects and effects on governmental budget have been calculated based on the best available data. The next section gives a brief description of the overall methodological approach and the input data used. Then, the applied calculation approaches and the results of the evaluated EEAP benefits are presented separately for each indicator. After a brief summary of the results, a critical reflection of the results is given in section 4 by discussing the main data and modelling uncertainties. The final section concludes, discusses further research needs as well as implications for the future energy efficiency policy strategy in Thailand.

\section{Evaluation approach}

This section gives a description of the overall methodological approach on how EEAP benefits have been calculated within this paper. More detailed descriptions of the calculations and the data used will be presented for each indicator in the following results sections. GIZ Thailand and experts of the Thai energy system have reviewed the calculation approaches and assumptions.

Five central benefits were of interest to this evaluation and are shown in Figure 2 and Table 1 . These include greenhouse gas savings $\left(\mathrm{CO}_{2}\right.$ equivalents), energy cost savings

\footnotetext{
${ }^{5}$ The EEAP includes values on expected energy savings, cost savings, $\mathrm{CO}_{2}$ reductions, but no information on the calculation approach and the assumptions.

${ }^{6}$ The quantification of rebound effects is outside the scope of this study.
} 
(by sectors) and energy import cost savings (by carrier), energy efficiency investments, employment effects, and effects on governmental budget.

A basic evaluation approach is taken with a series of equations to calculate each indicator. The bases of all calculations and central input variable of the ex-ante analysis are the energy savings (as given in the EEAP) expected to result from the policies to be implemented within the EEAP framework stated in thermal energy savings $\Delta q_{t h s}(t)$ as well as electricity savings $\Delta q_{e l s}(t)$ per sector s and year $t$ (data table included in annex 1). The EEAP energy savings are then combined with further input data collected from diverse sources (for details see section 3 ) in order to estimate the resulting benefits. Figure 2 gives an overview of the specified approach.

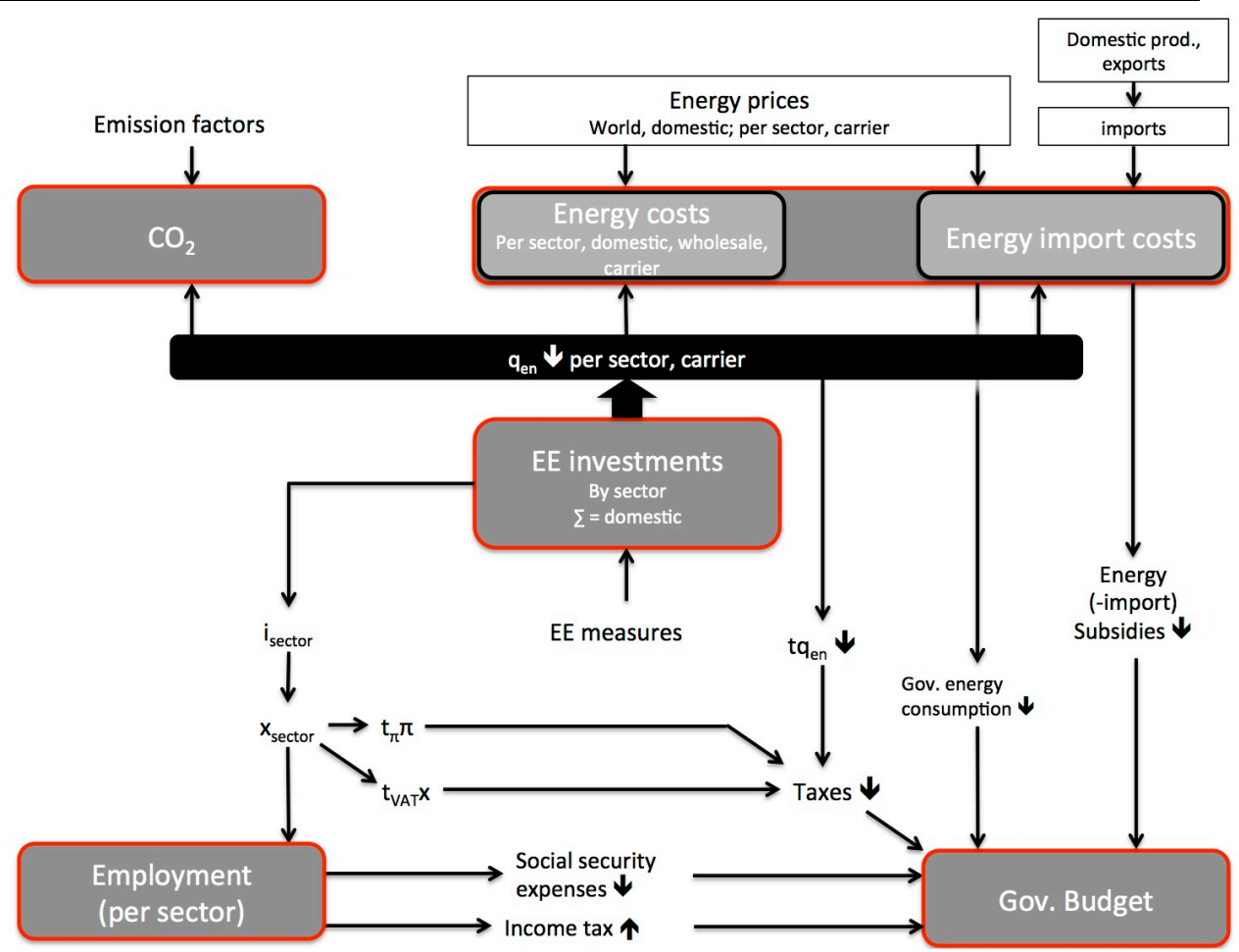

Figure 2 Schematic overview of the evaluation approach

Note: $q=$ (energy) quantities, $t=$ taxes, $\boldsymbol{\pi}=$ profits, $x=$ turnover .

Greenhouse gas savings are calculated directly from energy savings estimated in the EEAP impact assessment by multiplication with the respective emission factors per energy carrier. Energy cost savings build on the sector-wise multiplication of respective energy demands and relevant energy prices while import cost savings draw on energy import prices.

For the estimation of investments, we reviewed the literature and used the most appropriate data for the costs of saved energy (in terms of geographic provenience, actuality, availability; see respective section for data sources) to recalculate the investment that is necessary for realising the expected energy savings. This approach was taken, as bottom-up data of energy efficiency investment costs were neither available in the existing impact assessments, nor in official statistics in Thailand. The output of this calculation was then used as input for the estimation of direct employment effects, because investment is at the same time to a certain extent additional turnover. Combining these figures on a sectoral basis with labour intensities allows to calculate direct employment effects.

The governmental budget is affected through various effect channels that were calculated along the best data available: positively by the reduction of governmental energy 
consumption and energy subsidies, additional revenues of value added tax (VAT) and income tax as well as reduced unemployement expenses; negatively by lower energy tax revenues.

Calculation methodologies for each sub-effect on the governmental budget vary: VAT, corporate and income tax revenue changes as well as decreased expenses for unemployment benefits were analysed by top-down recalculation. The average tax quota was calculated from total turnover and total tax payments, and then multiplied with the estimated additional turnover. Similarly, we derived a "social security payment rate" per unemployed person and multiplied this with the estimated additional employment figures for calculating the reduction in social security expenses. Governmental energy consumption was taken directly from statistics. Energy subsidies may have a substantial impact on the public budget, but reliable data for Thailand is scarce. Therefore, we drew on most recent IEA (2014b) data on Thai energy subsidies and calculated three scenarios: first, a complete subsidy phase-out until 2030, second, maintaining subsidy rates at current levels, and finally an average scenario. We also included foregone energy tax revenues to provide an encompassing picture. This is consistent with our overall approach: Where we found diverging data sources or calculation approaches we always chose the more conservative way, i.e. yielding lower effects.

Table 1 Overview of evaluation approaches by indicator

\begin{tabular}{ll} 
Indicator & Evaluation approach \\
GHG savings & $\begin{array}{l}\text { Energy savings (by energy carrier/final energy product) } \times \text { emission } \\
\text { factors }\end{array}$ \\
Energy cost savings by sectors & $\begin{array}{l}\text { Energy savings (by energy carrier/final energy products, sector) } \times \\
\text { domestic energy prices (forecast) }\end{array}$ \\
Energy import cost savings & Energy savings (by energy carrier) $\times$ import prices (forecast) \\
Energy efficiency investments & Energy savings (by sector) $\times$ first-year (up-front) cost of saved energy \\
Direct employment effects & Investment costs $\times$ labour intensities (by sector) \\
Effects on governmental budget & - Taxes $($ VAT and business tax): tax rate $\times$ investments \\
& - Reduced unemployment expenses: average expenses $\times$ additional \\
& employment, additional average income tax revenues \\
& - Governmental energy consumption: electricity savings in public \\
& buildings $\times$ public energy tariffs \\
- Reduced subsidies: energy savings (by energy carrier) $\times$ subsidy & rates $(3$ scenarios) \\
- Foregone energy tax revenues: energy savings $($ by energy carrier) & $\times$ energy tax rates (by carrier/final energy product) \\
\hline
\end{tabular}

In general, the evaluation quality of these EEAP benefits depends on the available input data and on the methods that can be applied using this data. We have used data for Thailand from the major databases of the Thai Government (National Statistical Office of Thailand, Energy Policy and Planning Office, Department of Alternative Energy Development and Efficiency, Bank of Thailand, the Revenue Department, National Economic and Social Development Board, see detailed references in section 3), the IEA and complemented it with data available in scientific literature. Where data was not available, reasonable assumptions were made based on relevant academic literature and taking the country-specific background of Thailand into account. While the calculations for the original research have been done using Thai currency Baht (THB), for this paper all values have been converted to Euro (EUR) with the exchange rate of 2013 of $1 \mathrm{EUR}=40.186 \mathrm{THB}$ (Bankenverband 2013).

In order to increase the precision of calculations, total final energy demand (FED) has been disaggregated to the lowest level of available data for the respective calculations. Figure 3 gives an overview on disaggregation levels. The total FED contains all final 
energy consumed in Thailand or a specific sector (agriculture, transport, commerce, industry, residential; highest aggregation level). The FED is split up into the final energy carriers (FEC) electricity, oil, gas, coal and renewables. The specific energy products belonging to these carriers are final energy products (FEP). For example, lignite is a FEP of the FEC coal.

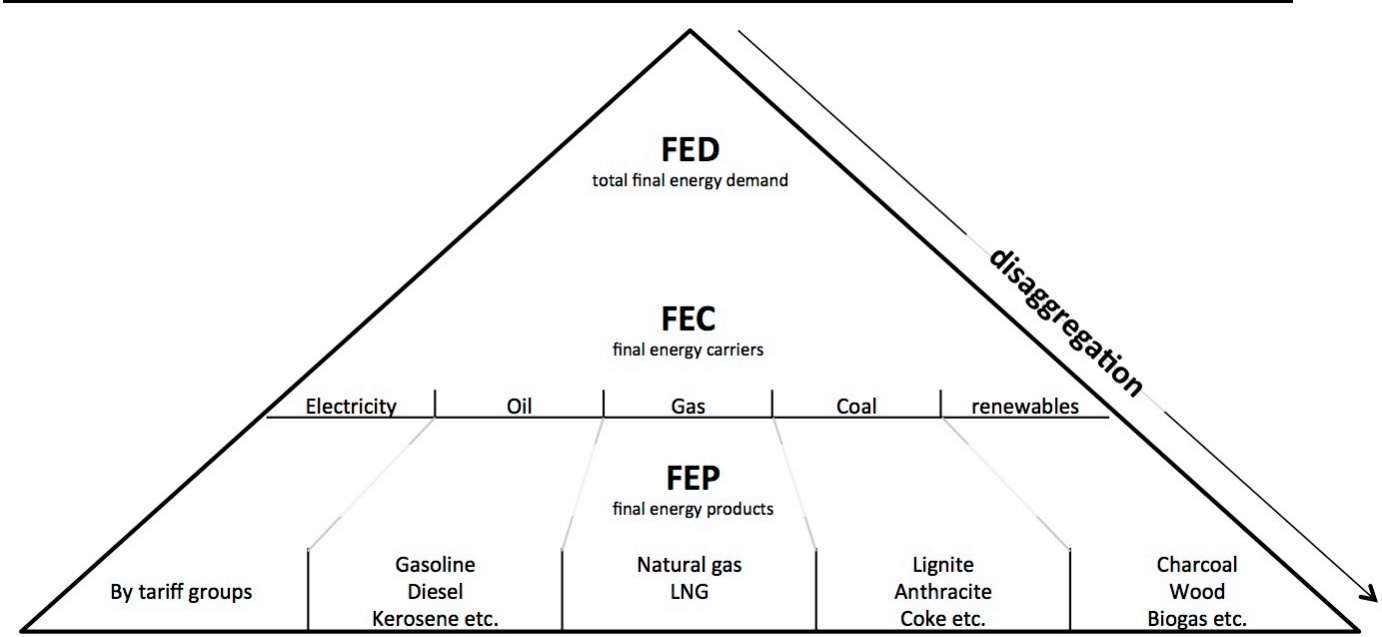

Figure 3 Final energy taxonomy

Note: The evaluation builds on prices and quantities for all FED, FEC and FEP where available.

The bases of all calculations are the provided energy savings of the policies to be implemented within the EEAP framework, stated in thermal energy savings $\Delta q_{t h s}(t)$ as well as electricity savings $\Delta q_{e l s}(t)$ per sector s and year $t$ in the EEAP. We further disaggregated thermal and electricity savings to final energy products.

These benefits of the Thai EEAP can in principle be analysed applying different evaluation methods including Computable General Equilibrium models (CGE), econometric models, Input-Output Analysis (IOA) or simpler methods such as cost-benefit analysis or spreadsheet calculation tools. The applicability and selection of the methods depends essentially on the data availability, whether indirect impacts and second-round effects should be assessed and the resources that can be committed to the analysis. CGE and macroeconometric models require a very good data base that was not available for this evaluation. The existing input-output table for Thailand did not allow for the estimation of all benefits of interest. Due to limited resources for this research and data availability, we applied a more simple approach that should give first insights and serve as a starting point for further research. Similar approaches were used e.g. by Erdmenger et al. (2009), Copenhagen Economics (2012), and for energy cost reductions (including uncertainty analysis) by Kaiser et al. (2004).

\section{Detailed calculations and results}

\subsection{Avoided greenhouse gas emissions $\left(\mathrm{CO}_{2 \mathrm{eq}}\right)$}

In 2012, total $\mathrm{CO}_{2 e q}$ emissions ${ }^{7}$ in Thailand were at $240 \mathrm{Mt}$ (EPPO 2013). Due to the reduction of final energy consumption, GHG emissions will be reduced accordingly relative to the $\mathrm{BAU}$ scenario. To calculate the $\mathrm{CO}_{2 \mathrm{eq}}$ emission reduction induced by the

\footnotetext{
${ }^{7}$ Emission estimations are based on $\mathrm{CO}_{2 \mathrm{eq}}$ emission factors from the EEAP and therefore include not only carbon dioxide but also other greenhouse gases as $\mathrm{CO}_{2}$ equivalents.
} 
EEAP, the respective energy savings of final energy products $\Delta q_{F E P}(t)$ were multiplied with the emission factors $f_{F E P}$ shown in Table $2 .^{8}$

\begin{tabular}{llll}
\hline \multicolumn{2}{l}{ Table 2 Thai emission factors by final energy products } \\
\hline Final energy product & Unit & $\begin{array}{l}\mathrm{CO}_{2} \text { emission factors }(f) \\
(\mathrm{t} \mathrm{CO} \text { eq } \text { per unit) }\end{array}$ & Source \\
Electricity & GWh & 561 & Ministry of Energy 2013 \\
Natural Gas & ktoe & 2,369 & Ministry of Energy 2013 \\
Coal & ktoe & 3,996 & Ministry of Energy 2013 \\
LPG & kt & 789 & Ministry of Energy 2013 \\
Bunker oil & million litre & 839 & Ministry of Energy 2013 \\
Biomass charcoal & thousand ton & 478 & Ministry of Energy 2013 \\
Benzene & ktoe & 2,927 & Ministry of Energy 2013 \\
Diesel & ktoe & 3,130 & Ministry of Energy 2013 \\
Jet fuel / kerosene & million litre & 2,575 & EPA 2011 \\
\hline
\end{tabular}

Source: Ministry of Energy (2013, Appendix C, p.457) and EPA (2011).

The overall amount is calculated by totalling the CO2eq reductions of all $\mathrm{n}$ final energy products.

$$
\text { (1) } \quad \Delta C O_{2 e q}(t)=\sum_{F E P=1}^{n} \Delta q_{F E P n}(t) \times f_{F E P n}
$$

Figure 4 shows an almost linear development of emission reductions until 2030 (according to the savings data from the EEAP). Annual emissions in 2030 could be reduced from $509 \mathrm{Mt}$ in the BAU case to $376 \mathrm{Mt}$ CO2eq, a reduction of $133 \mathrm{Mt}$ (see Figure 4), representing a reduction of about $26 \%$ of BAU emissions. This figure is largely consistent with the $140 \mathrm{Mt}$ GHG savings stated in the EEAP, but lacking calculation details (Ministry of Energy 2013, 41). Emission mitigation is mainly achieved by energy efficiency measures targeting electricity and oil consumption.

\footnotetext{
${ }^{8}$ For savings from "traditional" and "modern renewable energies" listed in the EEAP impact assessment, the emission factor for biomass/charcoal listed was applied.
} 


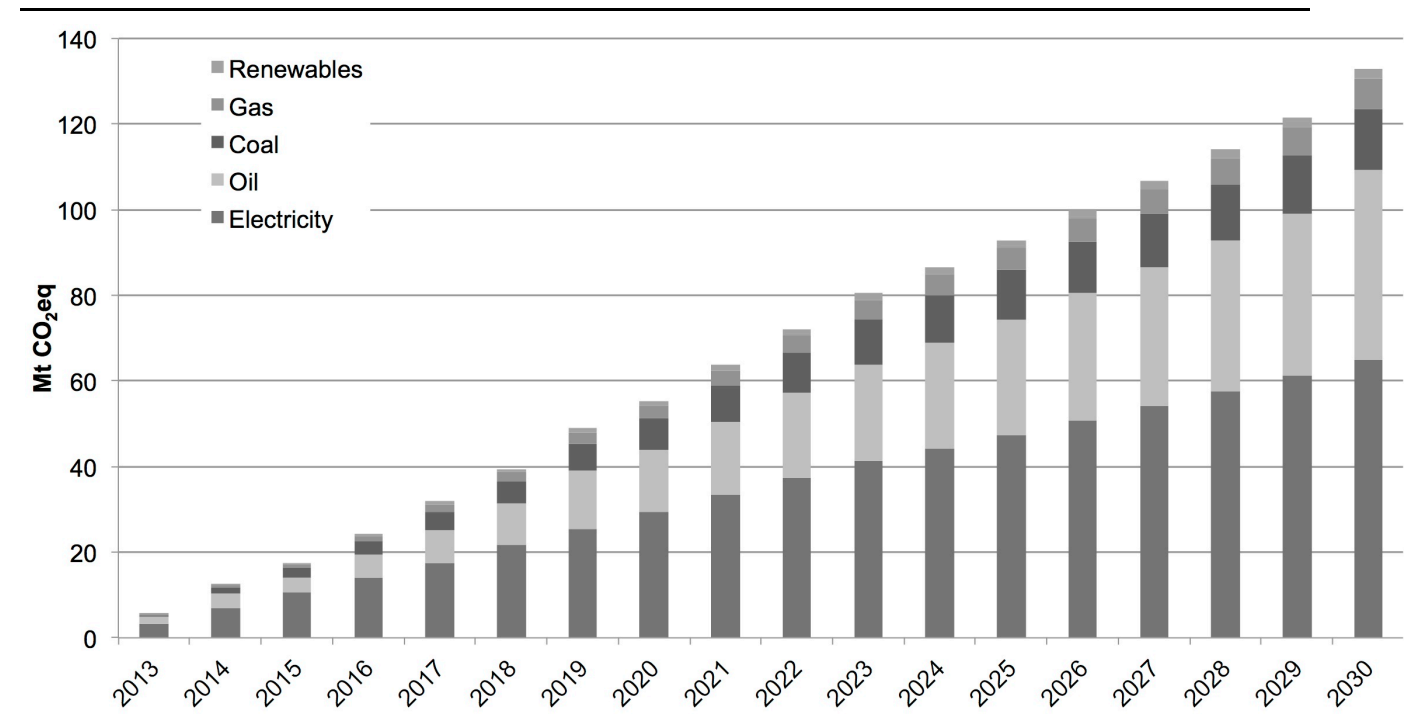

Figure 4 Avoided GHG emissions in $\mathrm{CO}_{2 \text { eq }}$ per year and energy carrier $\left(\mathrm{Mt} \mathrm{CO}_{2 \mathrm{eq}}\right)$

\subsection{Energy cost savings}

\section{Sector-specific energy cost savings}

The sector-specific energy cost reductions represent the benefits of the EEAP from a consumer perspective and are calculated by fuel type and for the agriculture, transport, commercial, industry and residential sectors. Final energy product prices for end-users $p_{F E P S}^{R T}$ including taxes, levies and marketing margin are considered for calculating the sector-specific energy cost savings. Based on the reduced consumption of all $n$ final energy products $F E P\left(\Delta q_{F E P S}\right)$ and respective retail energy product prices $\left(p_{F E P S}^{R T}\right)$, final energy carrier $F E C$ cost reductions $\triangle c_{F E C S}$ were assessed by aggregating the $F E P$ cost reductions, as shown in the following equation (2). Price rises have been oriented at the consumer price index (CPI). A conservative average price growth rate of $2 \% i_{p}$ per year (nominal) has been assumed in the forecasts. This value is oriented at the average consumer price index, which has increased in average of about $2.8 \%$ in the period 19982013 according to Bank of Thailand statistics (Bank of Thailand 2013a).

$$
\Delta c_{F E C S}(t)=\sum_{F E P=1}^{n}\left(\Delta q_{F E P S n}(t) \times p_{F E P S n}^{R T}\right) \times i_{p}{ }^{(t-2010)}
$$

For each sector $S$, the final energy demand FED and cost savings $\Delta c_{F E D S}$ are estimated by adding up all $m$ relevant energy carrier cost reductions.

$$
\Delta c_{F E D s}(t)=\sum_{F E C=1}^{m} \Delta c_{F E C s m}(t)
$$

The energy savings and resulting cost reductions are highest in the industrial and transport sector. By 2030, the EEAP is expected to lead to total annual consumer cost savings of 37.7 billion EUR (1.5tn THB) (Figure 5). This is a reduction of about $25 \%$ of total BAU energy costs. 


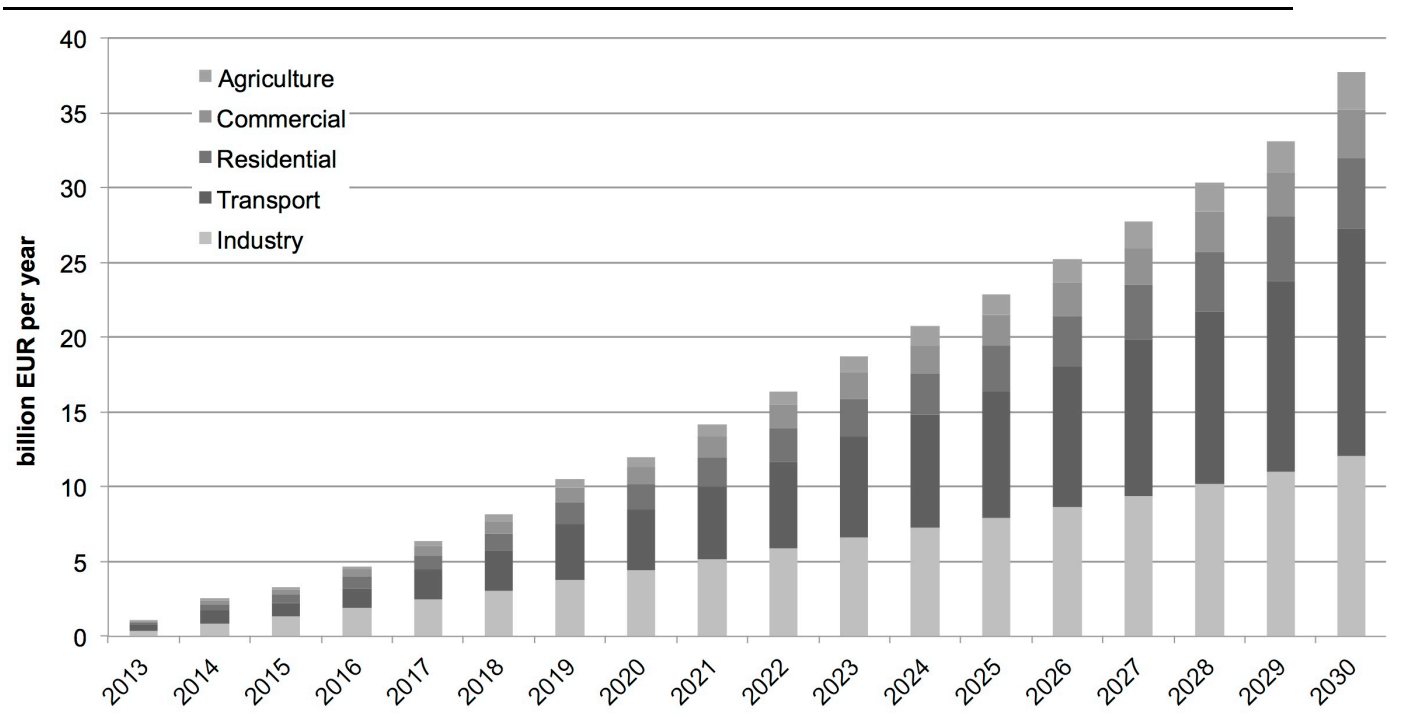

Figure 5 Energy cost savings per year and sector (bn EUR)

With regard to energy carriers, expenditures on final energy are reduced especially for petroleum products and electricity. This is essentially a result of the expected savings, which are highest for these energy carriers.

\section{Energy import cost savings}

In 2013, Thai energy demand was, to a large extent, met by energy imports due to very limited domestic resources. Therefore, import cost savings resulting from EEAP measures are of interest and assessed. As energy demand is expected to rise further due to economic growth, even with the EEAP implemented (see Ministry of Energy 2011) and Thai production capacities limited (IEA 2013a), we assume that all energy savings triggered by the plan will directly lead to reduced energy imports (relative to the BAU scenario). The monetary import cost savings are consequently calculated as the product of expected energy savings (as laid down in the EEAP by sectors and energy carriers) and world/Asia import energy prices and adjusted for future import price developments (assumption based on price growth forecasts: nominal price increase of $2 \%$ per year). A major share of the overall EEAP savings comes from electricity. Generation of electricity in turn needs primary energy inputs, end-use electricity savings were therefore converted to primary energy savings according to the Thai electricity generation mix (see Figure 6). We assume, that electricity imports from foreign hydropower will not be reduced.

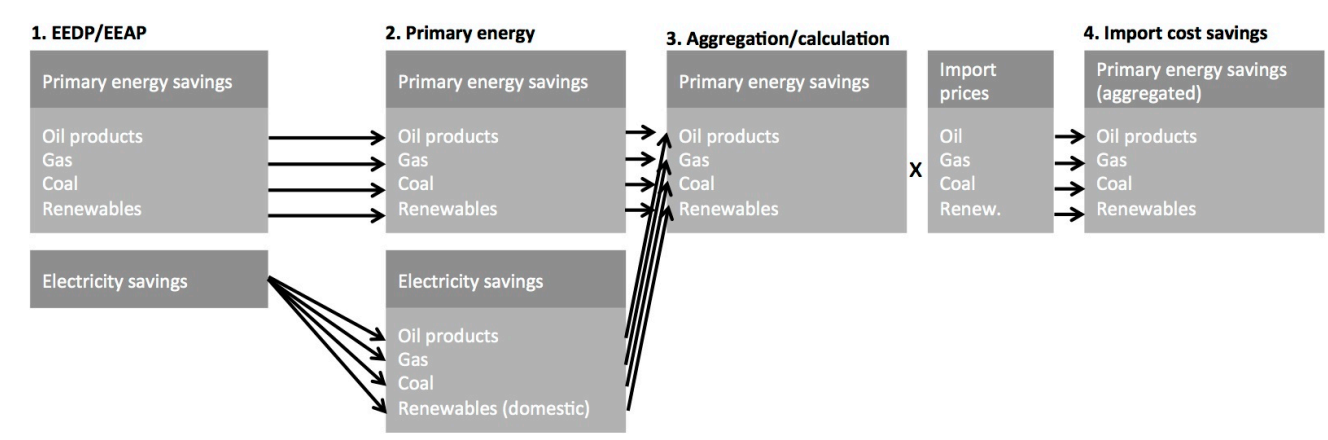

Figure 6 Calculation of import cost savings

To this end, the electricity generation capacity development as laid down in the Thai Power Development Plan (EPPO 2012) has been used for the primary energy conver- 
sion. ${ }^{9}$ The primary energy input shares of 2019 were used as a constant for the period 2020 to 2030 (Table 3) as primary input shares are expected to remain relatively constant for the period 2013-2019 by EPPO and no further projections were available. ${ }^{10}$

Table 3 Primary energy input shares for electricity generation

\begin{tabular}{|c|c|c|c|c|c|c|c|c|}
\hline Primary energy input (\%) & 2013 & 2014 & 2015 & 2016 & 2017 & 2018 & 2019 & $\begin{array}{l}2020- \\
2030^{b}\end{array}$ \\
\hline hydro & 9.0 & 8.8 & 8.9 & 9.7 & 10.3 & 10.6 & 11.1 & 11.1 \\
\hline natural gas/LNG & 63.4 & 62.0 & 63.2 & 59.0 & 55.6 & 57.1 & 58.3 & 58.3 \\
\hline fuel oil & - & - & - & - & - & - & - & - \\
\hline diesel & - & - & - & - & - & - & - & \\
\hline lignite & 9.4 & 8.8 & 8.3 & 7.8 & $7 \cdot 4$ & 7.0 & 6.6 & 6.6 \\
\hline import. Coal & 9.9 & 11.2 & 10.7 & 15.0 & 18.7 & 17.6 & 16.7 & 16.7 \\
\hline renewable & 1.3 & 1.4 & 1.3 & 1.3 & 1.2 & 1.1 & 1.1 & 1.1 \\
\hline small power producers & 6.4 & 7.0 & 6.7 & 6.3 & 6.0 & $5 \cdot 7$ & $5 \cdot 4$ & $5 \cdot 4$ \\
\hline very small power producers & 0.3 & 0.3 & 0.4 & 0.4 & 0.4 & 0.5 & 0.5 & 0.5 \\
\hline EGAT TNB ${ }^{\mathrm{a}}$ (imports) & 0.4 & 0.5 & 0.5 & 0.4 & 0.4 & 0.4 & 0.4 & 0.4 \\
\hline
\end{tabular}

Source: EPPO $(2012,83)$. Note: Due to typical planning and realisation periods, generation from nuclear plants is expected not to take place within the period analysed.

a Note: Transnational connection with Malaysian Provider Tenaga Nasional Berhad (TNB).

${ }^{b}$ Note: Lacking other forecasts, we used 2019 figures as assumption for the period 2020-203O.

Figure 7 shows saved energy import costs by energy carrier in billion EUR. In 2030, the largest share of energy import cost savings stems from oil and petroleum products (62\%). Gas and coal import costs are also significantly reduced due to a large amount of electricity savings.

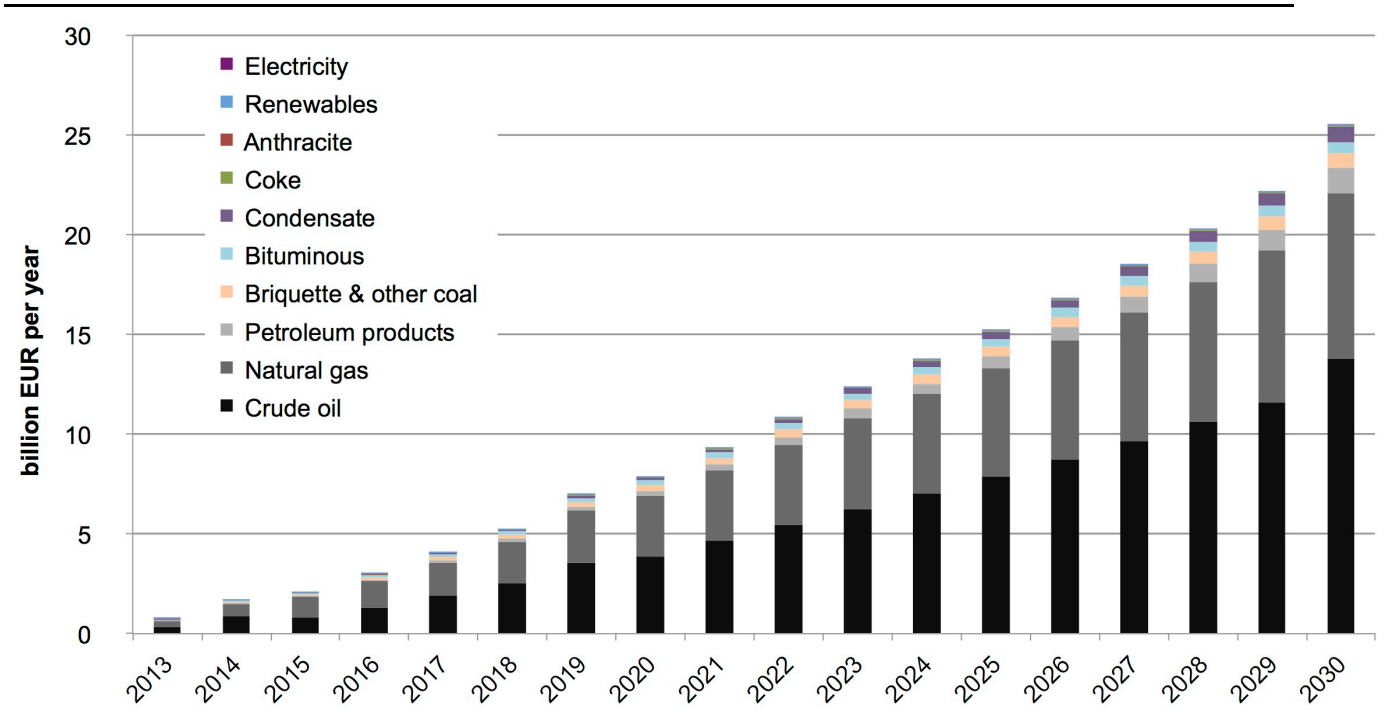

Figure 7 Energy import cost savings per year and energy carrier (bn EUR)

Note: for petroleum products, electricity and renewables, estimated figures are too small to be visible in the graph

In 2012, total Thai energy import expenditures amounted to about 34.2 billion EUR $(1,375$ tn THB) (EPPO 2013). This means, $12 \%$ of GDP is already spent on energy imports. Based on GDP extrapolations from the EEAP (Ministry of Energy 2013), the

\footnotetext{
${ }^{9}$ For the conversion of end-use electricity to primary energy, a conversion factor of 2.5 has been applied. This factor results from average Thai electricity generation efficiency of about 40\% (Enerdata 2014).

${ }^{10}$ In practice, reductions in energy demand may impact the relative share of energy products (and the power plant loading order), as well as line losses (operating at capacity vs. below capacity). These effects can have significant impacts on greenhouse gas emissions, but cannot be treated here.
} 
share is expected to rise to almost $20 \%$ of GDP in $2030 .{ }^{11}$ The EEAP may limit rising energy demand and thus reduce import expenditure shares to about $16 \%$ in 2030. Hence, the import dependency decreases significantly relative to BAU. According to our analysis, realising the overall EEAP energy savings may save the Thai economy around $4 \%$ of its projected 2030 GDP due to saved energy import costs (Figure 8).

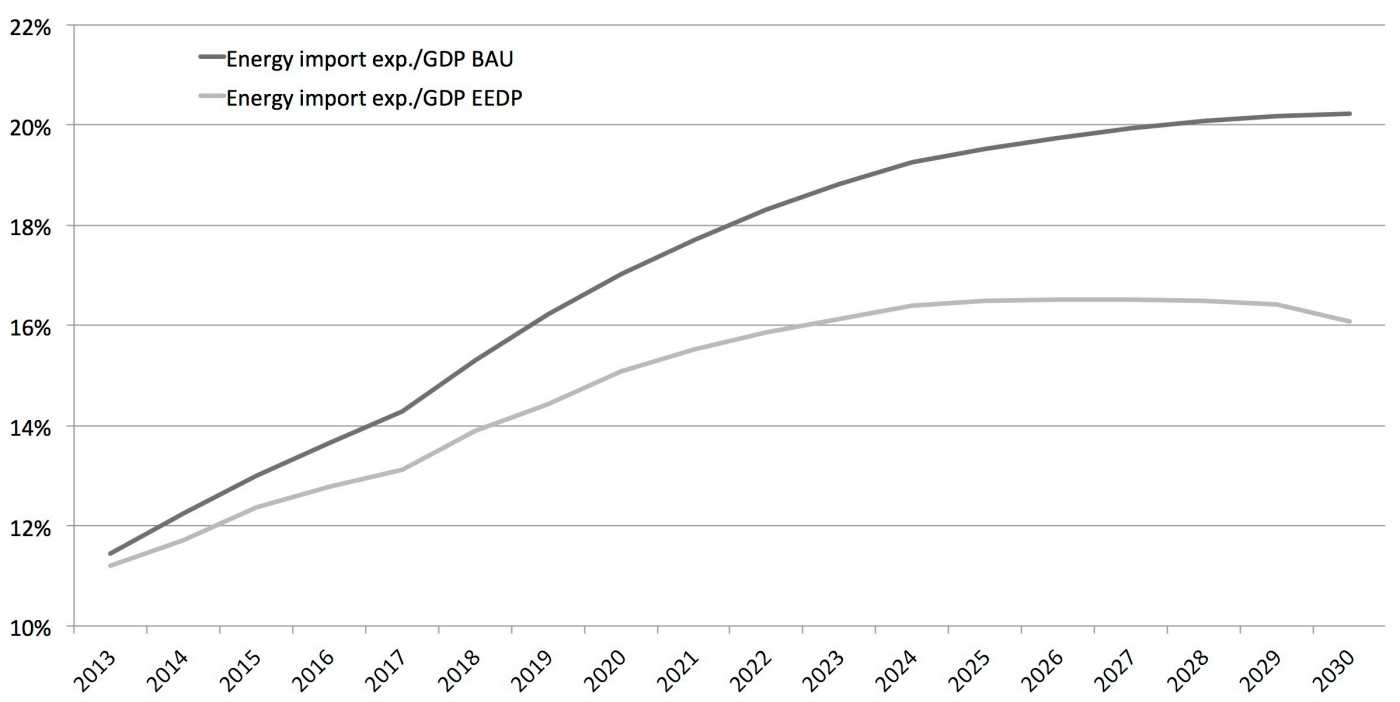

Figure 8 Energy import expenses as share of GDP

If global energy prices will rise at a higher (lower) annual rate than the assumed nominal $2 \%$, eg. by $3 \%$ (1\%), the picture may look differently: While in the BAU scenario, the GDP share of energy import expenses may rise to about 25\% (17\%) in 2030, the this may be reduced by the EEAP to about $19 \%$ (13\%), a reduction of about 6 (4) percentage points.

\subsection{Energy efficiency investments}

Energy efficiency gains and energy savings result from investments into more efficient technologies. Therefore, most impact assessments of energy savings report the implemented energy efficiency measures, the induced investments and the resulting energy savings. This was not the case for the EEAP and we had to draw on a different approach.

In the energy efficiency literature, the so-called cost of saved energy is often used as an indicator comparing different measures. The most common indicator are levelized costs of saved energy, defined as the present value of investment costs of technologies (I) divided by total lifecycle energy savings. First-year costs of saved energy (CSE ${ }^{1 s t}$, see e.g. Molina, 2014, 7), differ only in the denumerator, which contains first-year energy savings $\left(S_{\text {annual }}\right)$.

$$
\text { (4) } \quad C S E^{1 s t}=\frac{I}{S_{\text {annual }}} \Leftrightarrow I=\frac{\operatorname{CSE}^{1 s t}}{S_{\text {annual }}}
$$

As data for private sector investments into energy efficient technologies were not available for the Thai EEDP and EEAP, the investments had to be inferred from savings by backward induction, i.e. the investments necessary for realising the energy savings were derived from the (first-year) costs of saved energy and annual savings (see eq. 4). Programme costs such as financial incentives, tax rebates etc. are not relevant for this

\footnotetext{
${ }^{11}$ This calculation is based on the assumption of average GDP growth of 4.3\% (Ministry of Energy 2013). Estimates expect import expenses to rise from 34.2 billion EUR (1.4tn THB) in 2013 (EPPO 2013) to more than 120 billion EUR (5tn THB) in 2030 and are close to the forecast of IEA (2013).
} 
calculation. We have used the figures on cost of saved energy from the best available Thai data and the international scientific literature, and estimated typical investment per unit energy saved and combined it with the energy savings as expected by the EEAP.

Costs of first year saved energy were derived from the Thai DEDE 30\% Subsidy Programme $^{12}$ for the industrial sector, i.e. investment and savings data from actual implemented industrial measures in Thailand. This represents the most reliable data at hand. But as the 30\% Subsidy Programme only contains industrial energy efficiency measures, and that data for other measures is not available for Thailand, the data was adjusted for other sectors in addition to industry as follows:

First-year savings for other sectors were calculated by adjusting the DEDE figures with typical sector-cost-relations taken from the international literature (Loughran and $\mathrm{Ku}-$ lick 2004, DEDE 2013; Arimura et al. 2009; Auffhammer et al. 2008; Friedrich et al. 2009; Gillingham et al. 2004; Nexant 2003, 2012; UNU 1991a, 1991b; Vongsoasup et al. 2004; WEC 2013; details see table 3). The data from literature indicated lower costs of saved energy for thermal ( $t h$ ) than for electricity (el) measures, which is consistent with the generally found higher costs of electricity supply compared to fuel supply. Furthermore, $C S E_{t h}{ }_{\text {transportation }}$ was found to be higher than other thermal costs. Residential $C S E_{t h}{ }^{\text {residential }}$ and commercial $C S E_{t h}{ }^{\text {commercial }}$ costs are expected to be between these values. Literature analyses indicated higher costs for saving electricity $C S E_{e l}$. Costs of saved energy for commercial $C S E_{e l}{ }^{\text {commercial }}$ and industrial $C S E_{e l}$ industry $^{\text {measures were }}$

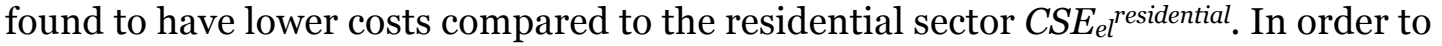
allow a comparison with the Thai data, the CSE were adjusted for currency as well as inflation and in several cases converted to ktoe $\left(C S E_{t h}\right)$ and $\mathrm{kWh}\left(C S E_{e l}\right){ }^{13}$ Although all data was adjusted to 2011 values by consumer price indices, the derived CSE data should be regarded as only preliminary estimations for Thailand. ${ }^{14}$ Considering the available data, this approach was the most reliable way to assess energy efficiency investments in Thailand. Table 4 shows the values of the lifecycle CSE as well as the inferred investment costs per first-year savings for Thailand.

\footnotetext{
${ }^{12}$ Energy efficiency subsidy programme in Thai industrial sector. Data on 428 energy efficiency measures are available to the authors.

${ }^{13}$ For currency adjustment, the following exchange rates were used: 1 U.S. Dollar $=31.218$ THB; 1 EURO $=40.186$ THB (July 06th, 2013 from Bankenverband (2013)). For energy unit conversion, conversion factors of Quasching (2013) were used.

${ }^{14}$ The external validity of non-Thai CSE values (i.e. their transferability) is questionable but the best approach at hand.
} 


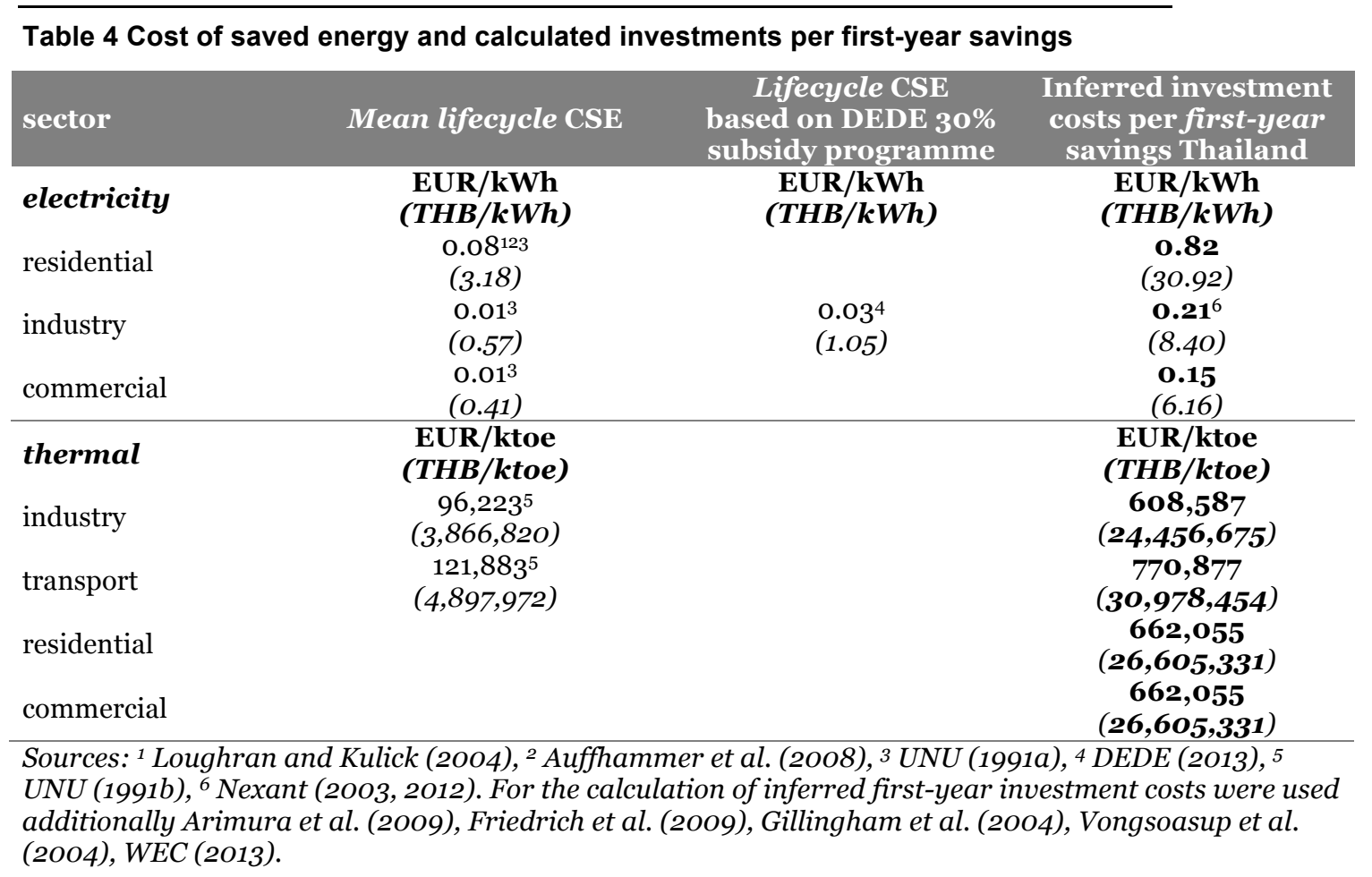

As shown in equation (5), yearly investment figures per sector $I_{s}$ were estimated by multiplying first-year costs of saved energy $C S E^{1 s t}$ with respective savings from the EEAP, electricity savings $\left(\Delta q_{e l s}\right)$ as well as thermal savings $\left(\Delta q_{t h s}\right)$ per sector and year ${ }^{15}$ :

$$
\text { (5) } \quad I_{s}(t)=\left[C S E_{\text {els }}^{1 s t} \times \Delta q_{\text {els }}(t)\right]+\left[C S E_{\text {ths }}^{1 s t} \times \Delta q_{\text {ths }}(t)\right]
$$

CSE values in the literature vary widely because of different measures, sectors and countries analysed. Due to the uncertainty associated with the CSE figures inferred for Thailand (see table 4), three scenarios were considered for calculating the induced EEAP investments: an average scenario, a low and high scenario deviating by $\pm 30 \%$ from the average scenario representing the large variance in CSE estimations from the literature. Figure 9 illustrates the expected annual investments resulting from the EEAP from 2011 to 2030 including the uncertainty corridor of $\pm 30 \%$.

Energy savings projected by the EEAP vary over time. Consequently, after a start-up period until 2014, the investments estimated to be necessary for realising those savings oscillate accordingly. The calculation yields energy efficiency investments of about 4.9 billion EUR (200bn THB) in 2030 in the average case ranging from 3.4-6.3 billion EUR (136-253bn THB) in the $\pm 30 \%$ uncertainty corridor. Investments from 2011 to 2030 total about 42 to 77 billion EUR (1.7 to 3.1tn THB). Estimated energy efficiency investments are between 2.5 and 5 billion EUR annually (100 to 20obn THB/year) from 2014 onwards.

\footnotetext{
${ }^{15}$ Note: This approach calculates additional investments in energy efficiency, irrespective of the financing source. The investments may either come from other sectors, crowding-out alternative investments or be additional if funded e.g. by additional credit programmes.
} 


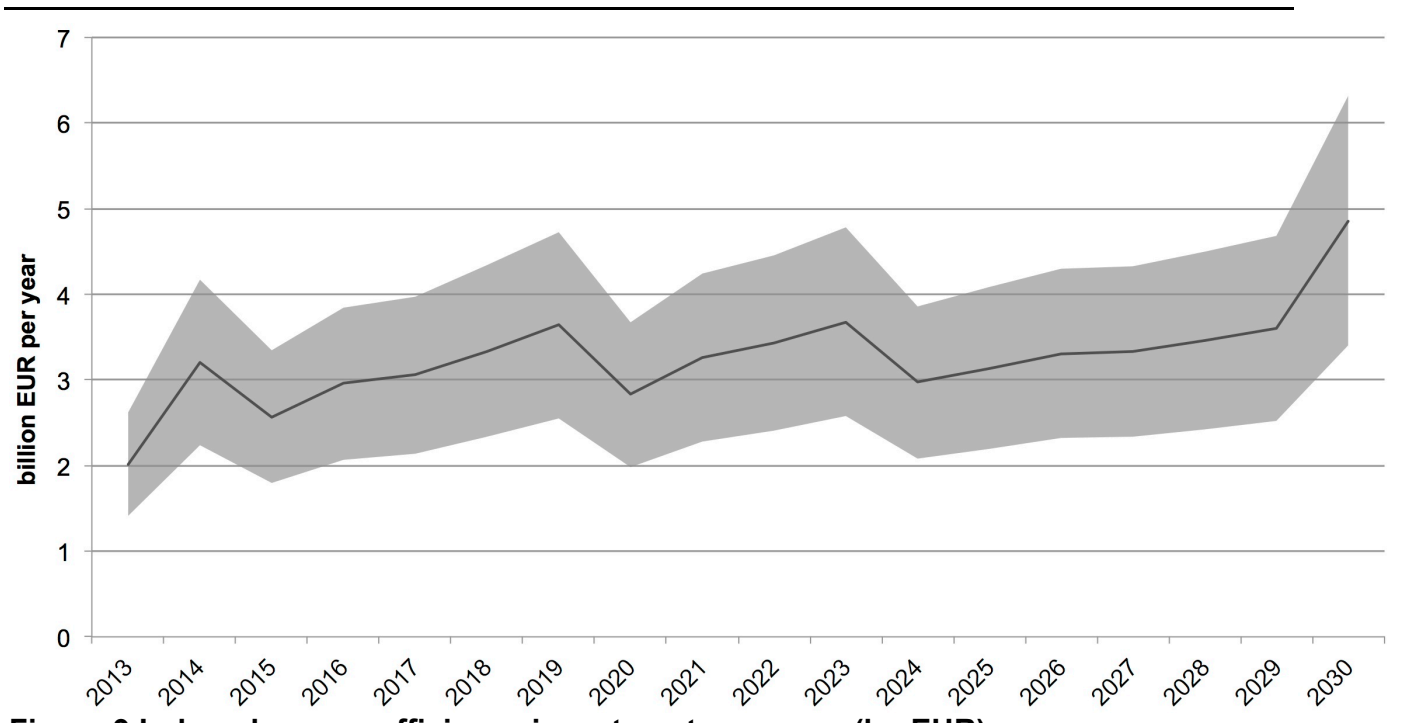

Figure 9 Induced energy efficiency investments per year (bn EUR)

Note: The shaded area depicts an uncertainty corridor of $\pm 30 \%$

\subsection{Employment effects}

A rough estimation of direct employment effects as a consequence of EEAP-induced economic stimulus resulting from investments in the energy efficiency goods and services has been conducted using Thai statistics of sectoral turnover and employment (NESDB 2013; Bank of Thailand 2013b). The following description and equation (6) explain the simplified approach followed here for assessing direct employment effects as a result of the induced energy efficiency investments. Due to the limited model complexity, the resulting employment figures should be interpreted as first rough estimations. As additional energy efficiency investments trigger turnover in the economic sectors providing energy efficiency goods and services, employment in these sectors will be stimulated. In order to derive employment effects from additional sectoral turnover, labour intensity by sector $s$ in Thailand has been calculated first (see Table 4). The data stems from Bank of Thailand (2013a, 2013b) (labour force survey) and NESDB (2013) (GDP) .

$$
\text { (6) } \quad l_{s}=\frac{L_{S}}{G D P_{S}}
$$

If the investment data estimated in the previous section are an indicator of additional turnover, and if the target sectors of these investments and the labour intensities are known, the product of investment data and labour intensities represent an indicator of direct employment effects.

Table 5 Employment, GDP and labour intensity per sector 2012

\begin{tabular}{|c|c|c|c|c|c|}
\hline Sector & $\begin{array}{l}\text { Employment } \\
\text { (1000 pers.) }\end{array}$ & $\begin{array}{r}\text { GDP } \\
\text { (Mio EUR) }\end{array}$ & $\begin{array}{r}\% \text { of labour } \\
\text { force }\end{array}$ & $\%$ of GDP & $\begin{array}{r}\text { Labour } \\
\text { intensity }\end{array}$ \\
\hline residential & 253 & 276 & $0.65 \%$ & $0.10 \%$ & 915.94 \\
\hline industry & 8,122 & 123,314 & $20.86 \%$ & $43.56 \%$ & 65.86 \\
\hline commercial & 10,369 & 72,887 & $26.63 \%$ & $27.65 \%$ & 142.26 \\
\hline transport & 926 & 14,748 & $2.38 \%$ & $5.21 \%$ & 62.78 \\
\hline agriculture & 15,434 & 34,732 & $39.63 \%$ & $12.27 \%$ & 444.36 \\
\hline public & 2,915 & 25,415 & $7.49 \%$ & $8.98 \%$ & 114.68 \\
\hline total & 38,018 & 271,373 & $98 \%$ & $98 \%$ & \\
\hline
\end{tabular}

Source: Own calculations based on data from Bank of Thailand (2013a, 2O13b), NESDB (2O13). 
To the amount that energy efficiency technology is imported and not produced within the country, additional turnover (and employment) will be induced in the exterior. However, as the domestic and foreign investment shares of the target sectors $\alpha_{s}$ are not known, Thai energy market experts of GIZ were interviewed. Based on these expert recommendations sectoral investment $\left(I_{s}\right)$ allocation has been assumed: $\alpha_{\text {ind }}=40 \%$ to Thai industry, $\alpha_{\text {com }}=30 \%$ into Thai commercial sector and $\alpha_{f o r}=30 \%$ to foreign providers. The resulting foreign effect is not included in the following figures. These additional sector-wide investments were combined with sectoral labour intensities $l_{s}$. The labour intensity indicates the number of employees needed for generating turnover. Whereas the commercial sector requires about 142 employees to generate one million EUR, the industrial sector only needs 66 employees. The employment effect per sector is then

$$
\text { (7) } \quad L_{s}=I \alpha_{s} l_{s}
$$

and the total employment effect by year $t$ across all sectors $S$ (industry, commercial) is

$$
L(t)=\sum_{s=1}^{S} I \times \alpha_{s}(t) \times l_{s}(t)
$$

On the basis of estimated investments (including $\pm 30 \%$ uncertainty, see previous section), assumptions and labour intensities, employment effects for the industrial and commercial sectors were calculated. In 2030, if energy savings are realised as projected, there may be an expected increase in employment in the range of approximately 230 to 430 thousand employees (Figure 10). Due to increasing energy efficiency investments from 2011 to 2030, the linear employment trend is positive as indicated by a simple least-squares-fitted line of the average effect. However, as indirect effects such as the income effect (utilisation of monetary savings from energy efficiency) has not been accounted for in the calculation, the resulting employment effect might be even more uncertain than depicted here.

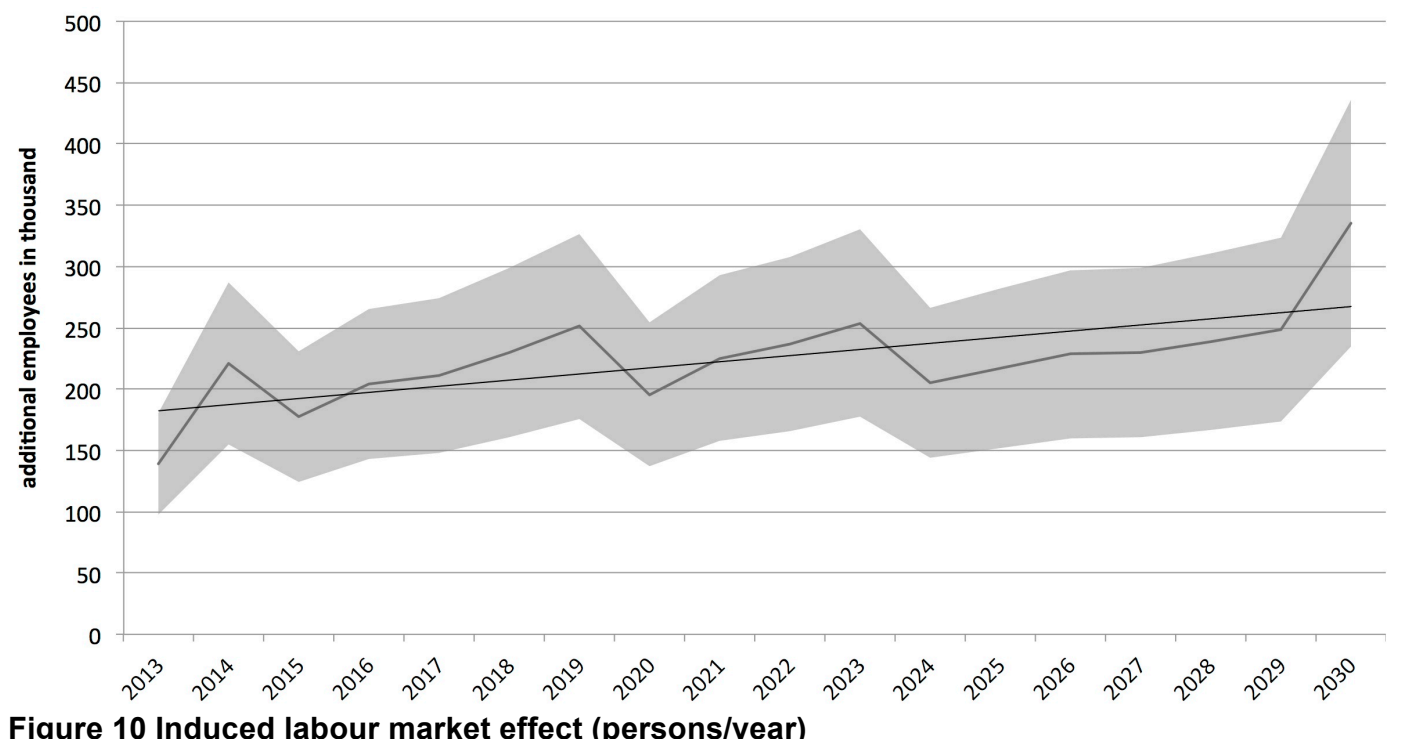

Figure 10 Induced labour market effect (persons/year)

Note: mean labour market effect with $\pm 30 \%$ uncertainty corridor and simple least-squares trend line.

For the evaluation of more precise and indirect labour market effects, more complex methods such as input-output-analysis (IOA) or computable general equilibrium models (CGE) should be applied in the future (IEA 2014). Such models can assess static effects resulting from additional turnover in sectors providing EE goods, financingrelated effects (depending on source of additional investments, potential crowding-out, second-round effects (resulting from indirectly affected sectors, especially calculated with IOA), price effects of demand reduction and resulting reallocations and substitutions (especially calculated with CGE models), effects from reallocation of energy cost 
savings to 1) increased energy consumption (direct rebound), 2) into consumption of other goods (indirect rebound) or 3) to monetary savings. Altogether, indirect effects are substantial and may even outweigh direct effects. For a more thorough estimation, they should therefore be accounted for in future evaluations. A general overview on labour market effects of energy efficiency investments can be found in e.g. IEA (2014), Bell (2011) and Schneck et al. (2010).

\subsection{Effect on governmental budget}

The total effect on the public budget is the sum of various positive and negative effects resulting from changing tax revenues and expenses (see as well Figure 2). The following sections briefly describe the five effects estimated in this study, additional information is provided in the annex. ${ }^{16}$

\section{Corporate and value added tax revenues}

Additional energy efficiency investments lead to increased turnover in the economy, which results in increasing corporate and value added tax (VAT) revenues (The Revenue Department 2013a, 2014). The estimation of corporate tax effects builds on the estimation of additional energy efficiency investments and increased turnovers in the economy, which results in increasing corporate revenues that are being taxed. Thai corporate tax rates vary from $10 \%$ (for international banks, foreign company profit repatriation) to over $15 \%$ (small companies) to $25 \%$ for stock-listed companies (see annex for an overview).

Corporate tax rates are not average, but rates on net profits after deduction of depreciations and other allowances. For deriving additional tax revenues from additional turnover, either detailed statistics on the Thai business structure would be needed (which were not available) or average tax rates. Therefore, we chose a simple approach in order to estimate this expectedly positive revenue effect on governmental budget for this analysis: The average tax quota $\tau_{\text {corp }}$ was derived from the turnover of the industrial, commercial and transport sector (obtained from statistics of NESDB (2011)) and from corporate tax revenues from these sectors (obtained from the Revenue Department 2013) with the most recent data available (2010-2012).

$$
\tau_{\text {corp }}^{\text {total }}=\frac{1}{3} \sum_{t=2010}^{2012} \frac{T_{\text {corp }}(t)}{G D P(t)}
$$

The average calculated Thai corporate tax quota for all sectors for the years 2010-2012 was $6.5 \%$ of total revenues. The VAT rate is at $7 \%$ (The Revenue Department 2014), we therefore used an overall average rate for corporate taxes and VAT of $\tau_{c o r p+V A T}=13,5 \%$. Increasing tax revenues due to the EEAP were thus estimated as the tax income on additional revenues (investment, $I$ ).

$$
\text { (10) } \quad T_{\text {corp }+V A T}(t)=I(t) \times \bar{\tau}
$$

The expected additional tax revenues amount to 460-850 million EUR (18-34bn THB) in 2030 (uncertainty due to uncertain additional investment/turnover).

\section{Income tax revenues and expenses for unemployment benefits}

Positive developments of employment figures affect the governmental budget twofold: by increasing personal income tax revenues and by decreasing government spending on unemployment schemes (decreased social security expenses) (The Revenue Department 2013b). Both effects have been roughly evaluated. For the first effect (income tax), average income tax payments in the affected sectors were estimated. This top-

\footnotetext{
${ }^{16}$ Direct policy implementation costs have not been considered in this evaluation.
} 
down approach yields more conservative estimates than the bottom-up approach. Figures on governmental income tax revenues $T_{t}$ were obtained from the Ministry of Finance, employment figures $(L)$ from the Bank of Thailand/National Statistical Office (Labour force survey) for the years $t=2010-2013$. From these figures, average income tax revenues per person were calculated.

$$
i=\frac{1}{3} \sum_{t=2010}^{2012} \frac{T_{\text {income }}(t)}{L(t)}
$$

Macroeconomic data yielded average income taxes of $153-175$ EUR per year $(6,150-$ 7,030 THB/year). We therefore applied average revenues of 164 EUR per person (6,600 THB/person; despite possibly higher taxes in the efficiency field, see figures above). For the total income tax effect per year, average income taxes $i$ were multiplied with employment effects $\Delta L$.

$$
\text { (12) } \quad T_{\text {income }}(t)=\Delta L(t) \times i
$$

For the second effect, contributions of the national government to social security schemes ("social protection", excl. health schemes; BOT 2013a) were divided by the number of persons not in the labour force/potentially receiving payments (NESDB 2011). Resulting average contributions per person were calculated at 935 EUR per year (37,590 THB/year) and multiplied with the positive employment effect. The estimated positive outcome (higher income tax revenues and lower social security expenses) totals about 140 million EUR (5.5bn THB) in 2030.

\section{Governmental energy consumption}

If public energy consumption decreases due to the EEAP measures implemented, energy expenses for the government are also directly reduced. EPPO (2013) states electricity consumption by tariff types. Our estimation uses the quantities and prices as stated in the MEA/PEA-tariff "Gov. \& Non-profit" (EPPO 2013) as a basis. GIZ Thailand estimated the NGO consumption share to be $3 \%$ within this tariff. We have therefore assumed a power consumption share by governmental institutions of $97 \%$ of this tariff classification. If the governmental share of total electricity consumption remains constant over time, the governmental electricity expenditures are expected to decrease by 250 million EUR per year (10.2bn THB/year) in 2030. Since governmental expenditure for other fuels is not considered as respective data was not available, this value represents a conservative estimate that may be higher in reality.

\section{Energy subsidies}

A number of cross-subsidies exist in Thailand's Energy sector. Energy subsidies in this study are defined in line with IEA as "any government action directed primarily at the energy sector that lowers the cost of energy production, raises the price received by energy producers, or lowers the price paid by the consumers" (IEA 2014b). In the subsidies guide for Thailand, the IISD (2013) mentions that "the main inputs to Thailand's electricity generation - natural gas and lignite - may also be provided at below-market rates." For other energy carriers, the existence of subsidies is indicated but detailed figures are not shown for all carriers and the unavailability of data is mentioned (IISD 2013). We therefore draw on IEA data from the 2014 World Energy Outlook (2014b), which is based on a price-gap approach "involving a comparison between national prices and international benchmarks" (IEA 2014b, 316) in order to calculate national and global energy subsidies. For further information on the methodology vis-à-vis IEA's calculation of subsidies, see IEA (2014b, 313). The IEA lists average energy subsidies 
(expressed as a proportion of the full cost of supply) in Thailand of $6.7 \%$ and total subsidy values by energy carriers (oil, gas, coal and electricity). ${ }^{17}$

From total energy costs calculated above and the IEA-figures, we derived subsidy rates by energy carriers for the year 2013. We then calculated three scenarios: 1) a constant rate scenario assuming constant subsidy rates until 2030 (high scenario), 2) a phaseout scenario assuming a linear phase-out of subsidy rates until 2030 and 3) an average scenario with rates declining to half of the 2013-rates until 2030 (see Table 6).

As in many low and middle-income countries, Thailand partially subsidises energy to support low-income households spending a relatively large share of their disposable income on energy. A complete phase-out of subsidies seems not likely due to strong public opposition. On the other hand, with rising energy demand over time, maintaining subsidies at current levels would continuously increase financial pressure on public budgets. A scenario between these two extremes seems therefore most realistic.

Table 6 Subsidy scenario overview (subsidies in \% of end-use energy prices)

\begin{tabular}{lllll} 
& & \multicolumn{3}{c}{2030 scenarios } \\
\cline { 3 - 5 } Energy carrier & 2013 & phase-out & average & constant rate \\
Oil & 7.4 & 0 & 3.7 & 7.4 \\
Gas & 11.8 & 0 & 5.9 & 11.8 \\
Coal & 22.8 & 0 & 11.4 & 22.8 \\
Electricity & 1.3 & 0 & 0.7 & 1.3 \\
\hline Source: own calculations based on IEA $(2014 b)$ & &
\end{tabular}

Source: own calculations based on IEA (2014b).

The derived subsidy rates are multiplied with the above-calculated energy cost reductions in order to obtain the avoided total subsidy costs. Consequently, the three scenarios yield very different levels of avoided subsidies in the year 2030: 1) if subsidy rates remained at current levels, avoided subsidies would amount to 1.9 billion EUR ( $78 \mathrm{bn}$ THB), 2) if subsidies were completely phased out until 2030, avoided subsidies would then accordingly be o (although, in previous years, when the phase-out is not yet complete, subsidy savings would occur) and 3) if rates were at intermediate levels, 2030subsidy savings would be at 1 billion EUR (39bn THB).

\section{Energy taxes}

Decreasing energy sales reduce energy tax revenues. With regard to this effect we have to remark that typically, foregone tax revenues are not included in evaluations. We took this approach here to provide an encompassing picture. Effects were estimated based on all available data on Thai energy price structures and respective energy taxes (DEDE 2013; EPPO 2013; APEC 2012). Lower energy tax revenues due to reduced energy demand constitute the most negative effect on the governmental budget, with petroleum product savings having the largest effect. Overall foregone tax revenues (excise tax and municipality tax) are approximately 1.8 billion EUR (72bn THB) in 2030.

\section{Net effect on governmental budget}

Due to the limited data availability, the absolute level of the total effect on governmental budget is not very reliable and should rather be regarded as a directional indicator in consideration of all assumptions. Equation (13) below illustrates the calculation of the net effect on governmental budget by aggregating the individual effects discussed in the previous sections.

\footnotetext{
${ }^{17}$ In a previous version of this paper (Suerkemper et al. 2014), we used data from World Energy Outlook 2013. Note that IEA has revised Thai subsidy figures for the years 2011-2012 substantially and published new data for 2013 in the 2014 World Energy Outlook (IEA 2014b). For this study, this led to a downward revision of subsidy figures by about $2 / 3$.
} 
(13)

$$
\begin{aligned}
\Delta c_{G B}(t) & =\Delta T_{F E D}(t)+\Delta c_{e l}(t)+\Delta s(t)+T_{\text {corp }}(t)+T_{\text {income }}(t) \\
\text { with } & \\
\Delta c_{G B} & \text { net effect on governmental budget } \\
\Delta T_{F E D} & \text { foregone energy tax revenue } \\
\Delta c_{e l} & \text { cost reduction governmental energy consumption } \\
\Delta s & \text { subsidy cost reduction } \\
T_{\text {corp }} & \text { additional corporate tax and VAT revenue } \\
T_{\text {income }} & \text { additional income tax revenue and reduced social } \\
& \text { security expenses } \\
t & \text { year }
\end{aligned}
$$

The expected average net effect in 2030 on the governmental budget induced by the EEAP is with +0.22 billion EUR positive (Figure 11). Taking into account major uncertainties, a wide range of -1 to +1.4 billion EUR $(-40$ to $+57 \mathrm{bn}$ THB) seems possible in 2030 (Figure 12). The large range of the results indicates the high uncertainty of the overall impact of the EEAP on the Thai governmental budget. However, as many effects are calculated conservatively in this study, and especially the largest effect of avoided subsidy costs may be very substantial, a positive net effect is likely. 


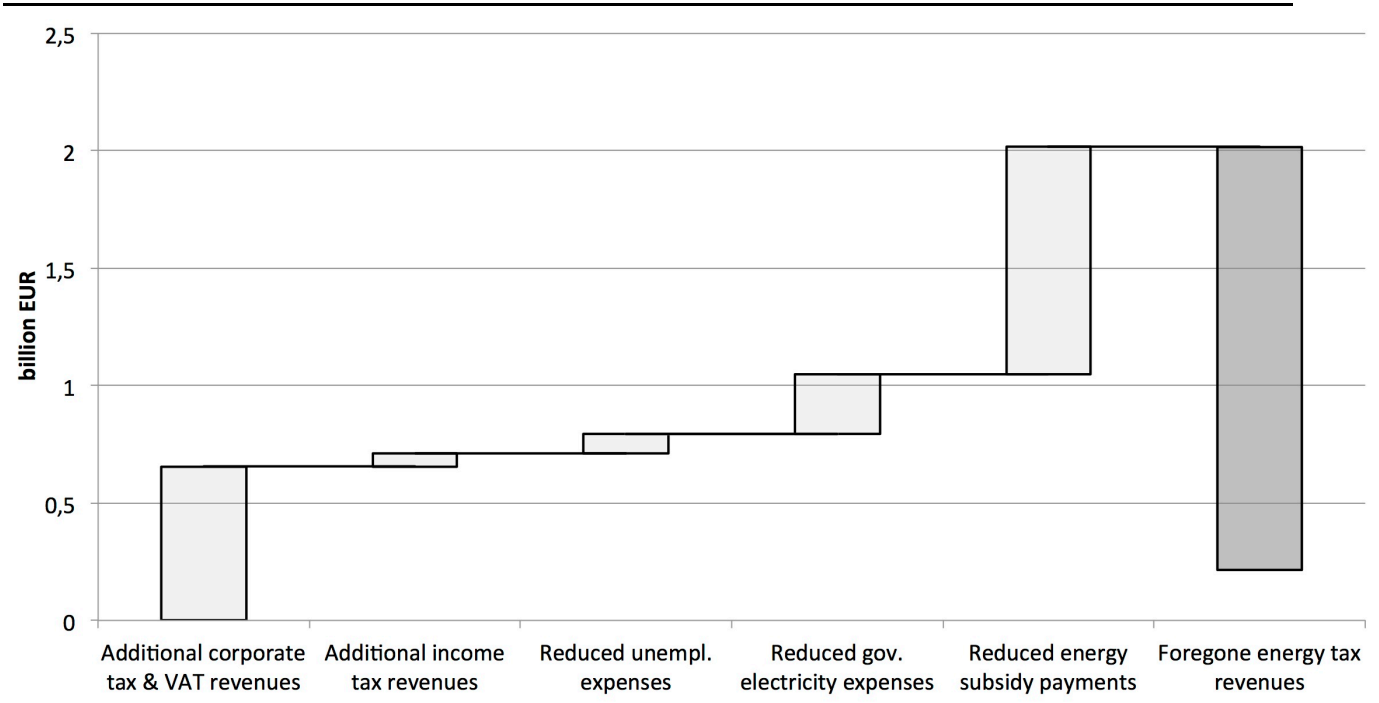

Figure 11 Composition of total effect on governmental budget in 2030 (average values)

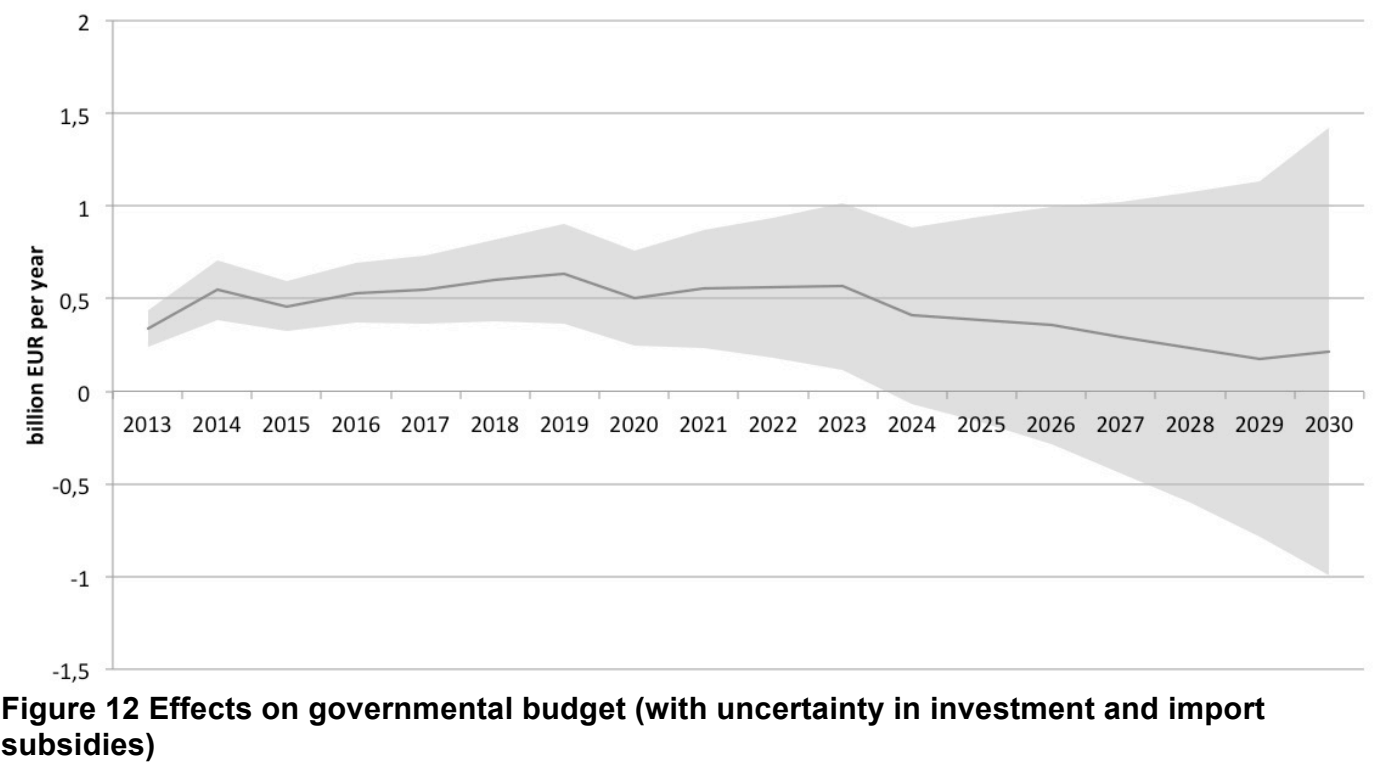

\subsection{Summary of results}

The implementation of the EEAP has various effects on the Thai economy. The ex-ante quantified effects in this report are summarised in Table 6 including the low, average and high scenarios for the investment, employment and governmental budget effects. By 2030, the plan is expected to lead to total energy cost reductions for consumers in Thailand of more than 37.7 billion EUR (1.5tn THB) relative to the BAU scenario, although there are many uncertainties as to many economy-wide effects that are yet to be investigated by more complex methods. Energy cost savings will be highest in the transport and industry sectors. Due to the high dependency on energy imports, the EEAP will also result in substantial energy import cost savings of more than 25 billion EUR (1tn THB). In 2030, the largest share of energy import cost savings stems from oil and petroleum products, but gas and coal import costs are also significantly reduced due to the large amount of electricity savings. Another important direct effect is the reduction of GHG emissions by $133 \mathrm{Mt} /$ year in 2030, mainly achieved by energy efficiency measures targeting electricity and oil consumption. The investments in energy efficiency, which will be generated through the implementation of the EEAP, will create additional employment in the Thai economy of approximately 230 to 430 thousand 
employees in 2030. The overall impact of the plan on the Thai governmental budget through several positive and negative effects will be positive, if there are substantial energy subsidies. By the year 2030, if subsidies are at half of today's rates, the total budget relief is calculated around 0.22 billion EUR (8.6bn THB).

Table 7 Summary of cumulated calculated EEAP effects in 2030

\begin{tabular}{|c|c|c|c|c|}
\hline \multirow[b]{2}{*}{ Effect } & \multirow[b]{2}{*}{ unit } & \multirow[b]{2}{*}{ low } & \multicolumn{2}{|c|}{ Impact in 2030} \\
\hline & & & high & average \\
\hline $\begin{array}{l}\text { Energy cost savings (con- } \\
\text { sumer perspective) }\end{array}$ & $\begin{array}{l}\text { bn EUR/yr } \\
\text { (bn THB/yr) }\end{array}$ & & & $\begin{array}{l}\text { total } 37.70 \\
(1,515)\end{array}$ \\
\hline Agriculture & & & & $\begin{array}{l}2.49 \\
(100)\end{array}$ \\
\hline Transport & & & & $\begin{array}{l}15.22 \\
(612)\end{array}$ \\
\hline Commercial & & & & $\begin{array}{l}3.22 \\
(129)\end{array}$ \\
\hline Industry & & & & $\begin{array}{l}12.04 \\
(484)\end{array}$ \\
\hline Residential & & & & $\begin{array}{l}4,72 \\
(190)\end{array}$ \\
\hline $\begin{array}{l}\text { Savings on energy import } \\
\text { costs }\end{array}$ & $\begin{array}{l}\text { bn EUR/yr } \\
\text { (bn THB/yr) }\end{array}$ & & & $\begin{array}{l}25.53 \\
(1,026)\end{array}$ \\
\hline Avoided $\mathrm{CO}_{2}$ emissions & $\mathrm{Mt} \mathrm{CO} / \mathrm{yr}$ & & & 133 \\
\hline $\begin{array}{l}\text { Induced energy efficiency } \\
\text { investments }\end{array}$ & $\begin{array}{l}\text { bn EUR/yr } \\
\text { (bn THB/yr) }\end{array}$ & $\begin{array}{l}3.40^{\mathrm{a}} \\
(137)\end{array}$ & $\begin{array}{l}6.32^{a} \\
(254)\end{array}$ & $\begin{array}{l}4.86^{a} \\
(195)\end{array}$ \\
\hline Employment effect (total) & 1000 employees & 235 & 436 & 335 \\
\hline Commercial & & 145 & 270 & 207 \\
\hline Industry & & 90 & 166 & 128 \\
\hline $\begin{array}{l}\text { Governmental budget effect } \\
\text { (total) }\end{array}$ & $\begin{array}{l}\text { bn EUR/yr } \\
\text { (bn THB/yr) }\end{array}$ & $\begin{array}{l}-0.99 \\
(-39.9)\end{array}$ & $\begin{array}{l}1.42 \\
(57.2)\end{array}$ & $\begin{array}{l}0.22 \\
(8.6)\end{array}$ \\
\hline Corporate tax & & $\begin{array}{l}0.46 \\
(18.4)\end{array}$ & $\begin{array}{l}0.66 \\
(26.4)\end{array}$ & $\begin{array}{l}0.85 \\
(34.3)\end{array}$ \\
\hline Energy taxes & & $\begin{array}{l}-1.80 \\
(-72.4)\end{array}$ & $\begin{array}{l}-1.80 \\
(-72.4)\end{array}$ & $\begin{array}{l}-1.80 \\
(-72.4)\end{array}$ \\
\hline Income tax & & $\begin{array}{l}0.04 \\
(1.6)\end{array}$ & $\begin{array}{l}0.07 \\
(2.9)\end{array}$ & $\begin{array}{l}0.06 \\
(2.2)\end{array}$ \\
\hline Social security expenses & & $\begin{array}{l}0.06 \\
(2.3)\end{array}$ & $\begin{array}{l}0.11 \\
(4.3)\end{array}$ & $\begin{array}{l}0.08 \\
(3.3)\end{array}$ \\
\hline $\begin{array}{l}\text { Governmental energy con- } \\
\text { sumption }\end{array}$ & & $\begin{array}{l}0.25 \\
(10.2)\end{array}$ & $\begin{array}{l}0.25 \\
(10.2)\end{array}$ & $\begin{array}{l}0.25 \\
(10.2)\end{array}$ \\
\hline Energy subsidies & & $\begin{array}{l}0 \\
(0)\end{array}$ & $\begin{array}{l}0.97 \\
(39.0)\end{array}$ & $\begin{array}{l}1.94 \\
(78.0)\end{array}$ \\
\hline
\end{tabular}

${ }^{\mathrm{a}}$ Note: investments are not cumulated, but additional investments per year in 2030.

\section{Discussion of results}

Ex-ante evaluations involve forecasting of a large variety of indicators, assessment of developments and extrapolation of data. Evaluation results depend on the combination and processing of this data. Consequently, the quality and reliability of the results depend on the data forecasting exercise. In general, Thailand does not have a "single national champion for energy efficiency" (Foran et al. 2010). Consequently, the current data base on efficiency measures, their savings potentials and costs in Thailand is very limited which is as well due to the incentive structure in the electricity generation sec- 
tor and consequent limited interest of the utilities in energy efficiency (Foran et al. 2010). ${ }^{18}$

In addition, the assessability of the reliability in turn depends on the transparency of the assumptions made. Therefore, this section briefly summarises the most important assumptions of the evaluation, important issues of the chosen methodological approaches and concerns with respect to the indicators evaluated.

Energy cost savings and import cost savings are largely dependent on the development of energy (import) prices. We built our analysis on existing price development assumptions and remained well below average Thai CPI developments of the last decade. This should yield rather conservative results for energy cost savings and reduced import costs.

For a precise evaluation of investment and employment effects, a complex macroeconomic model would be needed, e.g. a computable general equilibrium model, or an input-output-analysis. This was not possible within this study. Therefore, our results of investment and employment effects present first indications, which are, however, based on the best alternative methods available. There are two main uncertainties in the analysis: uncertainty about the level of investments and about the level and future development of energy subsidies. The first affects the employment effect and both uncertainties have an impact on the estimated size of the governmental budget effect. In order to account for the uncertainty in the results, we calculated a high and low scenario of $\pm 30 \%$ around average investment cost values derived from the literature (see investment section) and calculated three scenarios for the future development of energy subsidies. These sceanrios are included in the uncertainty analysis of the overall effect on governmental budget. Therefore, the uncertainty spread of the overall budget effect is large.

Taxation issues are particularly challenging to handle in an emerging country environment with scarce data availability. We decided to use top-down calculations for average tax rates to apply a consistent approach with the same data bases yielding more conservative results. Due to the many data issues, the absolute (average) level of the total effect on governmental budget is not very reliable and should rather be regarded as a directional indicator in consideration of all (conservative) assumptions taken. In addition, the phasing-out of subsidies, leads to a smaller budget impact of energy efficiency measures through reduced energy tax revenues. On the other hand, from a treasury perspective, a larger subsidy reduction leads to lower subsidy payments. This budget relief effect is not included the respective scenario calculations as it is independent of the EEAP.

\section{Conclusion}

This paper presents an analytical framework for a first ex-ante evaluation of the effects that a successful implementation of the Thai EEAP would have for Thailand's economy. Starting from the 20\% energy savings stated in the EEAP, we find that 37.7 billion EUR of final energy expenditures can be avoided by 2030, corresponding to a $20 \%$ reduction of overall BAU energy costs. Moreover, the energy savings will significantly decrease the import dependency and reduce the energy import costs of Thailand by more than 25 billion EUR in the future. Another important direct effect of the EEAP is a significant reduction of GHG emissions by $133 \mathrm{Mt} /$ year in 2030. In addition, private investment in energy efficiency will be generated through the implementation of the plan, which in turn creates additional employment in Thailand of approximately 230 to 430

\footnotetext{
${ }^{18}$ Greacen \& Greacen (2012) discuss how Thai utlities can be incentivised to promote energy efficiency.
} 
thousand employees in the energy efficiency sector in 2030. There is some uncertainty regarding the overall impact of the plan on the Thai governmental budget due to the different effects on corporate and income tax revenues, expenses for unemployment benefits, governmental energy consumption, expenses for energy import subsidies and energy tax income. The average expected effect is positive with around 0.22 billion EUR.

In summary, the evaluation results show that the key energy challenges for Thailand (energy supply security in terms of dependency on energy imports, continuously increasing energy costs, as well as increasing pollution and GHG emissions) could be addressed effectively through the achievement of the forecasted energy savings.

This study has also turned up several issues in need of further investigation and a number of limitations. The most important constraint is the limited availability of Thai data for the evaluation of several benefits. Therefore, we had to make respective assumptions or use data from international literature. In particular, more bottom-up cost data of energy efficiency technologies would help to calculate the induced energy efficiency investment and employment effects more accurately. Considerably more work is also due for the assessment of the EEAP-effect on employment. In order to also account for indirect effects on employment, more complex models such as input-output-analysis or computable general equilibrium models could be applied in the future.

Even if there are uncertainties in the evaluation results, the findings of this study have a number of important implications for future energy policy in Thailand. The key challenge for policy makers will be to actually realise the level of energy savings in the EEAP in order to achieve the full range of benefits for the economy and society. All regulations and policies included in the EEAP should be implemented effectively and in the near future, which will require close collaboration between all relevant Thai governmental institutions. At the same time, the policy measures will need to be accurately and comprehensively monitored and evaluated to allow for corrections of undesirable developments. Therefore, the establishment of a monitoring and evaluation system for energy efficiency allowing an intermediate and ex-post evaluation of the EEAP is an important task that should be paid attention to in Thailand. All of these activities should be accompanied by broad information campaigns for the public, high-quality education in the field of energy efficiency and capacity building activities for stakeholders in order to make the energy savings and the associated benefits in Thailand reality in the future.

\section{Acknowledgements}

The research was partly funded by the International Climate Initiative (ICI) of the German Federal Ministry for the Environment, Nature Conservation, Building and Nuclear Safety (BMUB). We are grateful for the very helpful and detailed comments of several anonymous referees which greatly improved the paper. We also thank Thomas Adisorn for his support in revising the paper and Gregory Scutt for proofreading. Helpful comments to an earlier conference version were also provided by IEPPEC 2014 panelists.

\section{References}

AIT (2010). Energy Security in Thailand. Asian Institute of Technology - School of Environment, Resources and Development, Pathum Thani.

APEC (2012). APEC Energy Statistics 2010. APEC Secretariat, Singapore.

Arimura, T.H., Li, S., Newell, R.G., Palmer, K. (2009). Cost-Effectiveness of Electricity Energy Efficiency Programs. Resources for the Future, Washington D.C.

Auffhammer, M., Blumstein, C., Fowlie, M. (2008). Demand-Side Management and Energy Efficiency Revisited. Center for the Study of Energy Markets (CSEM), Berkeley.

Bankenverband (2013). Währungsrechner. http://bankenverband.de/service/waehrungsrechner. Accessed o6 July 2013. 
BOT (2013a). Economic and Financial Data for Thailand. Bank of Thailand. http://www.bot.or.th/English/Statistics/Standard/SDDS/Pages/sdds.aspx. Accessed o7 May 2014.

BOT (2013b). Average wage, classified by industry, and employees for the whole Kingdom. Bank of Thailand. http://www.bot.or.th/Thai/Statistics/Standard/SDDS/Docs/Temp Wage.xls. Accessed o7 May 2014.

Bell, C. (2011). How Does Energy Efficiency Create Jobs. American Council for an Energy Efficient Economy.

Copenhagen Economics (2012). Multiple Benefits of investing in energy-efficient renovation of buildings, Report commissioned by Renovate Europe, Brussels.

CPUC (2001). California Standard Practice Manual (CSPM): Economic analysis of demand-side management programmes and projects. California Public Utilities Commission.

DEDE (2013). Thailand Energy Statistics 2012. Department of Alternative Energy Development and Efficiency - Ministry of Energy, Bangkok.

Du Pont, Peter T. (2014). Energy Efficiency: The First Fuel for Developing Asia. 5th International Conference on Sustainable Energy and Environment (SEE 2014): Science, Technology and Innovation for ASEAN Green Growth 19-21 November 2014, Bangkok, Thailand.

EDMC (2012). APEC Energy Database. Energy Data and Modelling Center, Institute of Energy Economics, Japan.

Enerdata (2014). Energy Efficiency Indicators. http://www.worldenergy.org/data/efficiency-indicators/. Accessed 22 January 2014.

EPA (2011). Emission Factors for Greenhouse Gas Inventories. Environmental Protection Agency. http://www.epa.gov/climateleadership/documents/emission-factors.pdf. Accessed 15 May 2014.

EPPO (2011). Energy Statistics of Thailand 2011. Energy Policy and Planning Office, Ministry of Energy, Thailand. http://www.eppo.go.th/info/cd-2011/. Accessed o7 September 2013.

EPPO (2012). Power Development Plan 2012 - 2030 (PDP2010: Revision 3). Energy Policy and Planning Office, Ministry of Energy, Thailand.

EPPO (2013). Energy Policy and Planning Office, Ministry of Energy, Thailand. http://www.eppo.go.th/info/indexstatistics.html. Accessed 23 September 2013.

EPPO (2014). Energy Statistics of Thailand 2014. Energy Policy and Planning Office, Ministry of Energy, Thailand. http://www.eppo.go.th/info/cd-2014/. Accessed 26 January 2015.

Erdmenger, C., Lehmann, H., Müschen, K., Tambke, J., Mayr, S., Kuhnhenn, K. (2009). A climate protection strategy for Germany-40\% reduction of CO2 emissions by 2020 compared to 1990. Energy Policy 37(2009), 158-165.

Foran, T., du Pont, P. T., Parinya, P., \& Phumaraphand, N. (2010). Securing energy efficiency as a high priority: scenarios for common appliance electricity consumption in Thailand. Energy Efficiency, 3(4), 347-364.

Friedrich, K., Eldridge, M., York, D., Witte, P., Kushler, M. (2009). Saving Energy Cost-Effectively: A National Review of the Cost of Energy Saved through Utility-sector Energy Efficiency Programs. American Council for an EnergyEfficient Economy (ACEEE), Washington D.C.

Gillingham, K., Newell, R.G., Palmer, K. (2004). Retrospective Examination of Demand-Side Energy Efficiency Policies. Resources for the Future, Washington D.C.

German International Cooperation (2015). Programme on Energy Efficiency Development Plan. http://www.thai-germancooperation.info/energy-efficiency-plan.html. Accessed 19 January 2015.

GIZ (2013). Newsletter of Bangkok-based projects by GIZ and partners. Issue 24, January-March 2013.

Greacen, C. S. and C. E. Greacen. 2012. Proposed Power Development Plan (PDP) 2012 and a Framework for Improving Accountability and Performance of Power Sector Planning. April 2012.

Greacen, C. E. and A. Palettu. 2007. Electricity sector planning and hydropower. Pages 93-126 in L. Lebel, J. Dore, R. Daniel, and Y. S. Koma, editors. Democratizing water governance in the Mekong region. Mekong Press, Chiang Mai.

IEA (2013a). Southeast Asia Energy Outlook. World Energy Outlook Special Report.

IEA (2014a). Capturing the Multiple Benefits of Energy Efficiency, OECD/IEA, Paris.

IEA (2014b). Fossil-fuel consumption subsidy rates as a proportion of the full cost of supply, 2012. World Energy Outlook 2014. http://www.iea.org/subsidy/index.html. Accessed 20 January 2015.

IEA (2015). Unit converter. http://www.iea.org/statistics/resources/unitconverter/. Accessed o6 January 2015.

IISD (2013). A Citizens' Guide to Energy Subsidies in Thailand. International Institute for Sustainable Development, Geneva.

Kaiser, M.J., Pulsipher, A.G., Baumann, R.H. (2004). The potential economic and environmental impact of a Public Benefit Fund in Louisiana. Energy Policy 32/2004, 191-206.

Loughran, D.S., Kulick, J. (2004). Demand-side management and energy efficiency in the United States. The Energy Journal, 19-43. 
Ministry of Energy (2011). Thailand 20-Year Energy Efficiency Development Plan (2011 - 2030). http://www.eppo.go.th/encon/ee-20yrs/eedp_eng.pdf. Accessed o7 July 2014.

Ministry of Energy (2013). 20-Year Energy Efficiency Action Plan. http://www.eppo.go.th/admin/km/20YearEEAP EN.pdf. Accessed o7 July 2014.

Molina, M. (2014). The Best Value for America's Energy Dollar: A National Review of the Cost of Utility Energy Efficiency Programs. Report Number U1402, ACEEE.

NESDB (2013). National Accounts of Thailand. Office of the National Economic and Social Development Board. http://www.nesdb.go.th

NESDB (2013). National Income of Thailand 2012 Chain Volume Measures. Table of National Accounts. Office of the National Economic and Social Development Board. http://eng.nesdb.go.th/Default.aspx?tabid=94

Nexant (2003). Benefit-Cost Data for DEDE 30\% Subsidy Program. Nexant Asia, Bangkok.

Nexant (2012). A Concept Note for Scaling up ADB's Energy Efficiency Investments: The Asia Energy Efficiency Accelerator. Asian Development Bank (ADB), Bangkok.

Phdungsilp, A. (2010). Integrated energy and carbon modeling with a decision support system: Policy scenarios for lowcarbon city development in Bangkok. Energy Policy, 38(9), 4808-4817.

Phdungsilp, A., Wuttipornpun, T. (2013). Analyses of the decarbonizing Thailand's energy system toward low-carbon futures. Renewable and Sustainable Energy Reviews, 24, 187-197.

Suerkemper, F., Thema, J., Thomas, S., Dittus, F., Kumpaengseth, M., \& Beerepoot, M. (2014). An ex-ante evaluation of the economy-wide benefits of the Thai energy efficiency action plan. IEPPEC 2014 conference paper.

Quasching, V. (2003). Energieeinheiten-Konverter. http://www.volkerquaschning.de/datserv/energierechner/index.php

Schneck, J., Murray, B.C., Gumerman, E., Tegen, S. (2010). Estimating the Employment Impacts of Energy and Environmental Policies and Programs Workshop Summary Report, Duke.

Shresta, R.M., Malla, S., Liyanage, M.H. (2007). Scenario-based analyses of energy system development and its environmental implications in Thailand. Energy Policy 35, 3179-3193.

Thepkhun, P., B. Limmeechokchai, S. Fujimori, T. Masui, and R. M. Shrestha. (2013). Thailand's Low-Carbon Scenario 2050: The AIM/CGE analyses of $\mathrm{CO} 2$ mitigation measures. Energy Policy 62, 561-572.

The Revenue Department (2013a). Corporate Income Tax. http://www.rd.go.th/publish/6044.o.html. Accessed 11 February 2014.

The Revenue Department (2013b). Personal Income Tax. http://www.rd.go.th/publish/6045.o.html. Accessed 11 February 2014.

The Revenue Department (2014). Value Added Tax. http://www.rd.go.th/publish/6043.0.html. Accessed 11 February 2014.

UNU (1991a). Thailand's demand side management initiative: a practical response to global warming. United Nations University. http://archive.unu.edu/unupress/unupbooks/80836e/80836E0w.htm. Accessed 11 February 2014.

UNU (1991b). Energy use in Indian industry: A case-study. United Nations University. http://archive.unu.edu/unupress/unupbooks/80841e/80841E07.htm. Accessed o9 July 2013.

Vongsoasup, S., Sinsukprasert, P., du Pont, P. (2004). An Energy-Efficiency Promotion Strategy for Industries and Buildings in Thailand. Industrial and Commercial Use of Energy Conference.

WEC (2013). Energy Efficiency Policies around the World: Review and Evaluation. World Energy Council. http://www.worldenergy.org/publications/energy_efficiency_policies_around_the_world_review_and_evalua tion/3_evaluation_of_energy_efficiency_policies_and_measures/1195.asp. Accessed o3 September 2013. 